IZA DP No. 9610

Effects of Unionization on Workplace-Safety Enforcement: Regression-Discontinuity Evidence

Aaron Sojourner

Jooyoung Yang

December 2015 


\title{
Effects of Unionization on Workplace-Safety Enforcement: Regression-Discontinuity Evidence
}

\author{
Aaron Sojourner \\ University of Minnesota \\ and IZA \\ Jooyoung Yang \\ University of Minnesota
}

\section{Discussion Paper No. 9610 \\ December 2015}

\author{
IZA \\ P.O. Box 7240 \\ 53072 Bonn \\ Germany \\ Phone: +49-228-3894-0 \\ Fax: +49-228-3894-180 \\ E-mail: iza@iza.org
}

Any opinions expressed here are those of the author(s) and not those of IZA. Research published in this series may include views on policy, but the institute itself takes no institutional policy positions. The IZA research network is committed to the IZA Guiding Principles of Research Integrity.

The Institute for the Study of Labor (IZA) in Bonn is a local and virtual international research center and a place of communication between science, politics and business. IZA is an independent nonprofit organization supported by Deutsche Post Foundation. The center is associated with the University of Bonn and offers a stimulating research environment through its international network, workshops and conferences, data service, project support, research visits and doctoral program. IZA engages in (i) original and internationally competitive research in all fields of labor economics, (ii) development of policy concepts, and (iii) dissemination of research results and concepts to the interested public.

IZA Discussion Papers often represent preliminary work and are circulated to encourage discussion. Citation of such a paper should account for its provisional character. A revised version may be available directly from the author. 
IZA Discussion Paper No. 9610

December 2015

\section{ABSTRACT}

\section{Effects of Unionization on Workplace-Safety Enforcement: Regression-Discontinuity Evidence ${ }^{1}$}

We study how union certification affects the enforcement of workplace-safety laws. To generate credible causal estimates, a regression discontinuity design compares outcomes in establishments where unions barely won representation elections to outcomes in establishments where union barely lost such elections. The study combines two main datasets: the census of National Labor Relations Board (NLRB) representation elections and the Occupational Safety and Health Administration's (OSHA) enforcement database since 1985. There is evidence of positive effects of union certification on establishment's rate of OSHA inspection, the share of inspections carried out in the presence of a labor representative, violations cited, and penalties assessed.

JEL Classification: J51, J28, I18

Keywords: $\quad$ union(s), OSHA inspections, workplace accidents, effects, labor market institutions

Corresponding author:

Aaron J. Sojourner

Carlson School of Management

University of Minnesota

321 19th Ave S 3-300

Minneapolis, MN 55455

USA

E-mail: asojourn@umn.edu

\footnotetext{
${ }^{1}$ We would like to thank Suyoun Han for excellent research assistance on this project, John Budd and Alison Morantz for helpful comments, and to the U.S. Department of Labor Emerging Scholars Program for financial support. Data on NLRB elections is posted at:

https://www.dropbox.com/s/m92aw4vb1u3qy0n/nlrb_elections_19622009.dta?dl=0

Data from OSHA inspections is posted at: http://ogesdw.dol.gov/views/data_summary.php
} 
IZA Discussion Paper No. 9610

December 2015

\section{NON-TECHNICAL SUMMARY}

Since 1970, the U.S. Occupational Safety and Health Act has defined federally-protected rights for private-sector workers to safe and healthy workplaces. The Occupational Health and Safety Administration (OSHA) works to uphold these rights through enforcement and education using its own agency resources directly and by leveraging partnerships with other organizations including state governments, research institutes, employers, and labor unions.

This paper studies the effects of unionization on workplace-safety law enforcement. We compare establishments where unions barely won union-certification elections to establishments where unions barely lost such elections. At the time of the election, these two sets of establishments are very similar. After the election, unions are certified as collectivebargaining agents in the former set of establishments but not in the latter set. Around the $50 \%$ vote-share threshold, this simulates an experiment where unionization is almost randomly assigned to establishments. Drawing on the OSHA enforcement database from 1985 to the present, each establishment experiencing an NLRB election in the last three decades is connected to any relevant OSHA inspection information.

In the years after the election, did the two sets of establishments experience different inspection probabilities, probabilities of having a labor-representative present on inspections, levels of violations cited, and levels of penalties assessed? These comparisons provide credible estimates of the local average treatment effects of union certification on the margin.

Union victory in close NLRB certification elections leads to increased occupational-safety law-enforcement activity and increased worker representation in the enforcement process. Union certification increases OSHA activity - inspection rates, violations cited, and penalties assigned - each by about 8 percent of a standard deviation. The results are remarkably consistent across outcomes. Further, conditional on having an OSHA inspection, union certification increases the share of inspections that have a labor representative participating by 27 percentage points. This provides the strongest evidence in the literature documenting a rights-facilitation effect of unions and shows that the level of law enforcement depends on the strength of interested, private institutions. 
Since 1970, the federal Occupational Safety and Health Act has defined federallyprotected rights for American, private-sector workers to safe and healthy workplaces. The Occupational Health and Safety Administration (OSHA) works to uphold these rights through enforcement and education using its own agency resources directly and by leveraging partnerships with other organizations including state governments, research institutes, employers, and labor unions. Under the Act, workplaces must meet specific standards and employees have rights to initiate OSHA inspections, to participate in inspections and in pre- and post-inspection meetings, and in administrative proceedings. Union activities may serve as a complement to OSHA's direct expenditures and enforcement efforts. If unions are effective, declining unionization in the private-sector workforce can make the Department of Labor's (DOL) job more difficult.

Labor unions tend to share the DOL's interests in ensuring safe and healthy workplaces. In collective bargaining and labor-management relations at unionized firms, they often push to increase health and safety along with improvements in other terms and conditions of employment. To some extent, unions educate workers about the nature of their legal rights, facilitate exercise of these rights, and work to ensure such rights are protected by encouraging vigorous enforcement against violations. Unionized workers may also be more likely to understand their rights under OSHA and to report specific potential health and safety violations, request inspections, and participate directly or through a labor representative in the inspection process.

Smith (1986) and Weil (1991) pioneered study of these processes. They provide thoughtful, thorough discussion of ways that unions can promote enforcement of workers' OSHA rights. ${ }^{2}$ Morantz (2011) provides a more recent look focused on the mining industry and the Mine Safety \& Health Administration (MSHA), which has a much more intensive regulatory regime than OSHA. To develop empirical evidence, Smith studies data at the industry-year level from 1977-1979 and observes a positive association between the unionization rate and the rate of worker-initiated complaint inspections controlling for a few other industry-year characteristics. Weil studies OSHA enforcement data combined with business-census data from the manufacturing industry in the year 1985. He compared union to nonunion establishments in a

\footnotetext{
${ }^{2}$ This is an example of a rights-facilitating effect of unions, a term coined by Budd \& McCall (1997) where they develop evidence unions help workers exercise their rights to access unemployment-insurance benefits.
} 
broad cross-section with respect to their inspection probabilities, probability of having a laborrepresentative participate in inspections, level of violations cited, and level of penalties. In each case, he found large differences between union and nonunion establishments. We extend the analysis beyond manufacturing to the whole private economy and beyond a single year of data to 27 years. Morantz controls for more observable factors than Smith or Weil could and also finds evidence of more intensive enforcement in unionized workplaces.

Interpreting those observed differences is a challenge given the prior data's limited ability to support tight comparison across otherwise-similar establishments. Perhaps unions do cause stricter enforcement through the mechanisms described above and, thereby, create the differences observed. Or, omitted variables that are correlated with both union status and outcomes could drive the outcome differences while unionization per se has no effect. For example, in establishments that are more dangerous, workers may be more likely to unionize and OSHA may be more likely to inspect, cite, and penalize. Without an ability to compare tightlysimilar establishments with respect to their underlying safety levels and propensities to unionize, it is difficult to credibly isolate the causal effect of unions.

To overcome this obstacle, regression discontinuity design (RDD) compares establishments where unions barely won National Labor Relations Board (NLRB) unioncertification elections to establishments where unions barely lost such elections (DiNardo \& Lee, 2004; Sojourner, Frandsen, Town, Grabowski, \& Chen, 2015). Rather than comparing union to nonunion establishments generally and relying on statistical controls and untestable identifying assumptions vulnerable to selection bias, we restrict attention only to establishments where employees indicated an interest in unionizing such that the NLRB held a union-certification election. At the time of the election, establishments where the union just won narrow elections are very similar to establishments where the union just lost such elections. After the election, unions are certified as collective-bargaining agents in the former set of establishments but not in the latter set. Around the 50\% vote-share threshold, this generates a quasi-random assignment of union certification to establishments and helps overcome the omitted-variables problem. Drawing on the OSHA enforcement database from 1985 to the present, each establishment experiencing an NLRB election in the last three decades is connected to any relevant OSHA inspection information. 
In the years after the election, did the two sets of establishments experience different inspection probabilities, probabilities of having a labor-representative present on inspections, levels of violations cited, and levels of penalties assessed? These comparisons provide credible estimates of the local average treatment effects of union certification on the margin. ${ }^{3}$ Further, we do the best the OSHA enforcement data allow to construct measures of occupational injury in each establishment and to analyze effects on injuries, though the data have substantial limitations for this purpose.

An important advantage of RDD over designs that simply try to adjust for observed differences in control variables is that the assumptions needed for RDD imply falsifiable conditions (DiNardo \& Lee, 2011). Like an experiment, there should not be any difference in the distribution of observable characteristics between the "treatment" and "control" groups prior to treatment. In our context, this means there should be no difference prior to the election between establishments where unions later barely win and those where they later barely lose. Analysis of the pre-election versions of the OSHA outcomes and characteristics of the establishments observed from the NLRB elections provide evidence on the validity of our design's assumptions.

We also study differences in the effect of unionization by establishment size to help add evidence on a cloudy issue in the literature: whether unions have bigger effects on enforcement in smaller or larger establishments. Weil's study of union effects on OSHA enforcement in manufacturing and Morantz's study of union effects on MSHA enforcement in mining found opposite relationships between the size of union effects and establishment size. Weil found effects were bigger in larger establishments. Morantz found effects were smaller in larger establishments. Similarly to Weil, we focus on OSHA enforcement activity as the outcome.

\section{Design and Data}

Index establishments by $\mathrm{i}=1,2 \ldots \mathrm{I}$ and suppose each has only one union-certification election. Interest centers on the average effect of the union winning an election, indicated by $D_{i}$. The forcing variable - that which governs selection into union certification - is the election's

\footnotetext{
${ }^{3}$ A limitation of the RDD is that it is most informative about the effects of the unions on the margin of certification, rather than their effects where unions are particularly strong. On the other hand, this is the most relevant margin to understand the effects of policy changes that would make it marginally easier or harder to get union certification, such as card check or speedier elections.
} 
pro-union vote-share $\left(X_{i}\right){ }^{4}$ As in Lee \& Lemieux (2010) and Sojourner et al (2015), the basic model for any given outcome $\left(Y_{i}\right)$ is:

$$
Y_{i}=D_{i} \tau+f\left(X_{i}\right)+W_{i} \delta+\varepsilon_{i}
$$

Union certification, $D_{i}$, depends deterministically on vote share, $D_{i}=1\left[X_{i}>0\right]$ and $f$ is assumed to be continuous at 0 . Other pre-election observable determinants of the outcome $\left(W_{i}\right)$, including lagged outcomes, can serve as control variables.

The causal effect of union certification near the certification threshold is identified as $\tau$ under the following continuity assumption on unobservable influences $\left(\varepsilon_{i}\right)$ :

$$
\lim _{x \uparrow 0} E\left[\varepsilon_{i} \mid W_{i}, X_{i}=x\right]=\lim _{x \downarrow 0} E\left[\varepsilon_{i} \mid W_{i}, X_{i}=x\right]
$$

This assumes that unobserved factors influencing the outcome do not jump in a discontinuous manner at the election-victory threshold. Because the only factor that can shift discontinuously at the threshold is union certification $(D)$, any observed differences in outcomes across the threshold after the election can be interpreted as the causal effect of union certification on the margin.

The study population is all U.S. private-sector establishments on the margin of unionization between 1985 and 2009 as measured by the establishment experiencing at least one NLRB certification election during this period. The study starts with January 1985 because this is the first year any occupational fatalities are recorded in the OSHA data. During this period, the NLRB election database contains 79,390 elections with a valid election month, election year, industrial classification code, state, establishment name, and counts of employees voting in favor of and against unionization. In some cases, the data contain establishment street address. ${ }^{5}$

Because any establishment can have multiple NLRB elections over time, a matching algorithm is used to construct longitudinal, unique-establishment identifiers. Across the set of

\footnotetext{
${ }^{4}$ We transform raw vote shares following DiNardo \& Lee (2004). We create 20 bins of width 5 percent and consider each establishment to have the vote share of the mid-point of its bin so that the possible values of $X$ do not vary with the number of votes cast in the election. We also re-center so that the union-victory threshold has the value zero.

${ }^{5}$ We integrate two databases that compile and standardize NLRB election records: one from Holmes (2006) that includes elections during 1977 to 1999 and which includes many establishments' street address and a second provided by Hank Farber covering 1962 to 2009 but lacking any street addresses.
} 
elections in establishments in the same state, city, and industry (strict match after cleaning), the algorithm links elections in establishments with similar names and addresses (fuzzy match after cleaning). This identifies 72,187 unique establishments represented in the 79,390 elections. ${ }^{6}$

Next, establishments with NLRB elections are linked to the OSHA enforcement database. The OSHA database records all administrative enforcement actions and some occupational injuries in U.S. private sector establishments from 1985 to 2012 (U.S. Department of Labor, 2014). This period includes $3,246,794$ inspection records across the U.S. private-sector economy. For each inspection, the establishment's name, address, city, state, and industry are observed.

Our focus is only on OSHA records from establishments that experienced NLRB elections. For each OSHA record, we look for a match among all the NLRB election records using strict matching of establishment's city, state, and industry along with fuzzy-matching on name and address. Using the NLRB-based establishment identifiers, this yields a longitudinal database of unique establishments each linked to any associated NLRB elections and OSHA enforcement data. This procedure produces links 48,671 OSHA records to 16,166 unique establishments that underwent NLRB certification elections. This implies that 22.4 percent of such establishments are linked to any OSHA record. The other 77.6 percent of establishments that underwent NLRB elections are measured to have no OSHA enforcement actions during the study period.

Analysis focuses on the subsample of NLRB elections meeting the following criteria:

1) At least 20 individuals voted: a vote-total floor minimizes the risk that the exact outcome could be manipulated by the company, the union, or workers, which would somewhat undermine the quasi-randomization across the vote-share threshold (Frandsen, 2012).

\footnotetext{
${ }^{6}$ The algorithm requires the researcher to choose weights to value matching text characters and penalize mismatches across records. The nuisance parameters were chosen by trying different values and inspecting samples of the matching results by hand to assess which delivered the best-quality matches. To assess sensitivity of final estimates to the parameter values, we also use two, alternative parameterizations to generate two alternative sets of establishment identifiers. Empirical results are re-estimated using the alternative identifier. Appendix A provides additional detail on the records-matching process.
} 
2) Election occurs between 1985 and 2009: before 1985, records of fatal injuries are almost completely absent from the OSHA database (Appendix Figure 5). ${ }^{7}$ Focusing on elections occurring after 1985 ensures a positive probability of observing occupational fatalities prior to the election, giving a meaningful pre-election injury measure for use as a control variable and in testing for valid RD conditions. Our NLRB election data end in 2009.

3) First such election observed in an establishment: Considering multiple elections for the same establishment raises a number of conceptual questions about whether an establishment should be considered as treated (union wins) or control (union loses). Focusing on only the first election meeting criteria 1) and 2) in each establishment sidesteps these thorny issues. This election is termed the establishment's focal election (Sojourner, Town, Grabowski, Chen, \& Frandsen, 2013). This is a conservative standard that may introduce some attenuation in estimated effects. ${ }^{8}$

Another issue raised by multiple elections is the possibility that unions or management learn enough through recently-past elections to manipulate the outcome of the election in such a way as to introduce systematic differences across the threshold in unobservables and, thereby, invalidate the identifying assumption. This concern diminishes as the time between elections extends. Therefore, any establishment that experienced an NLRB election, regardless of outcome, in the 5 years immediately prior to the focal election is excluded.

4) No evidence of prior unionization: Using the NLRB data back to 1962, any establishment where any union was certified prior to the focal election is excluded. This clarifies the interpretation of the treatment as a contrast between establishments

\footnotetext{
${ }^{7}$ Even after 1985, the OSHA fatality data is highly incomplete. The OSHA data records only about two-fifths as many fatal occupational as the more-complete Census of Fatal Occupational Injuries (CFOI) across the years both are available (Appendix Figure 6).

${ }^{8}$ If a subsequent election has the same result as the focal election, this does not introduce measurement error. If a subsequent election has the opposite result, we are less likely to find an effect. The establishment then truly has a mix of certified and not-certified units rather than having the pure status measured by the focal-election result.
} 
with no unions previously certified as bargaining agents and those with any union so certified (Sojourner, Town, Grabowski, Chen, \& Frandsen, 2013).

5) Valid number of votes: the number of total recorded votes must not exceed the number of eligible voters (bargaining-unit size).

Filtering on criteria 1 and 2 reduces the number of unique establishments and focal elections to 42,430. After implementing criteria 3, 4 and 5, the number of unique establishments shrinks to our analytic sample is 31,052 establishments. As described at the top of Table 1, the average raw vote share was 49 percent and the average number of eligible voters was 107 . In the analytic sample, 26.2 percent of establishments have at least one linked OSHA record from between January 1985 to December 2011, similar to the link rate in the overall NLRB sample. The other 73.8 percent have no linked OSHA record.

\section{Outcome measures}

Five outcome variables are measured for each establishment. Relative to each establishment's unique focal election, a post-election and a pre-election measure of each variable is constructed. Post-election measures serve as outcomes, contrasted across the certification threshold to estimate the union-certification effect. Pre-election measures serve three purposes. First, they allow for falsification testing. The assumptions of RDD imply the testable prediction that there should be no discontinuity in the distribution of pre-election observables across the threshold. Second, they serve as control variables to reduce bias that may arise from violations of the RDD conditions. Third, they increase estimates' precision by helping explain post-election outcomes and, thereby, reducing the role of unobservable influences.

We develop three measures of the intensity of OSHA enforcement activity at each establishment in the post-election period and one measure of labor's active involvement in the inspection process. First, to measure each establishment's inspection rate, count the number of post-election inspections, those between the focal-election month and the end of the study period (December 2011). Compute the length of the establishment's post-election period similarly in years: post-election months/12. The post-election inspection rate is the count of inspections over the length of the period or, equivalently, the average number of inspections per year post- 
election. Measure pre-election inspection rates analogously using January 1985 as the start of the study period. In the pre-election period, the average annual inspection rate is 0.04 with standard deviation 0.21 , implying an average of 4 inspections performed annually per 100 establishments in our sample with a standard deviation of 21. Post-election, the annual inspection rate is 3 per 100 establishments. ${ }^{9}$

Second, the exercise of walkaround rights (Weil, 1991) is measured by the share of inspections attended by a labor representative at each establishment in each period. In the preelection period, an average of 2 percent of inspections were attended by labor representatives. For research purposes, it is heartening that this share is so low because the sample is constructed to focus on establishments with no union representation in the pre-election period. However, for program purposes, it is sobering evidence that workers rarely exercise their rights to participate in OSHA inspections absent a union. Further, pre-election labor-representative share can serve to control for differences in pre-election unionization across establishments that our sampleconstruction rules miss. ${ }^{10}$ Second, analyzing the effect of certification on the share of postelection inspections attended by labor representatives generates empirical evidence on the extent to which certification drives unionization per se. Evidence that certification lifts the share of post-election inspections attended by labor representatives would give validity to the interpretation of a certification effect as informative about unionization effects. Third, this provides an estimate of the effect on exercise of federal walkaround rights, the most credible evidence on a union rights-facilitation effect in the literature.

Third, combining multivariate data on each establishment's OSHA violations yields a single index measuring the establishment's degree of OSHA violations cited. For each inspection at an establishment, OSHA assigns a number of current violations for each of 5 types of violations: Serious, Willful, Repeated, Other, and Unclassified. Figure 1 displays an example of the kind of violation and penalty data available from each inspection. We focus on Serious, Willful, and Repeated violations because Other and Unclassified violations are extremely rare. For each establishment and each of the three types of violation, sum the number of violations

\footnotetext{
${ }^{9}$ Establishments in our sample - those that experienced NLRB elections - appear more likely to be inspected than establishments in general. For 2014, OSHA reports a total of 83,380 federal or state-plan inspections. The Bureau of Labor Statistics reports 9.1 million private-sector establishments in 2014Q3. This implies the annual inspection rate is 0.9 inspections per 100 establishments overall.

${ }^{10}$ A labor representative may attend inspections prior to the focal election if workers organized prior to 1962 or outside the NLRB process, or if our linking process missed a longitudinal match to a prior union election victory.
} 
across all post-election inspections and divide through by years at risk. Do the same for the preelection period. This measures the average annual number of violations of each type in each period. The distribution of these are highly-skewed with large masses at zero violations. Logtransform using $\log (1+$ average number of violations per year $)$ to reduce the influence of outliers. Motivated by the idea that the three types of violations are all generated by a single, latent establishment propensity to violate, factor analyze the three pre-election log-violation-rates across establishments to find the single latent factor that explains the most variance in violation rates, obtain scoring coefficients, and score each establishment based on its three, measured preelection log-violation-rates. ${ }^{11}$ Using the same scoring coefficients, score each establishment in the post-election period using its three, measured post-election log-violation-rates. To give the index a meaningful scale, standardize in the post-election control group, the set of establishments where the union loses the focal election. That is, we compute the mean and standard deviation of the index in this subsample and then use these moments to standardize all pre- and post-election observations. There is little difference between average violation indexes pre- versus postelection (Table 1). The minimum of -0.24 and maximum of 71.06 post-election shows that, even with log-transformations, the index remains skewed.

This approach has many advantages. It pools information across three highly-correlated violation measures to yield a single, low-noise, post-election measure for use as an outcome. It also provides a single pre-election control variable, rather than three that would likely suffer from multicollinearity. By reducing both measurement error in the outcome and multicollinearity in the predictors, this approach should boost the precision of estimated certification effects $(\hat{\tau})$.

One disadvantage of the approach is that the units of this violations index are not easily comparable to the conventional, count-of-violations measure. To address this, we offer the following. We divide the set of establishments in the post-election control group into percentiles based on values of the violation index. Each percentile contains about 175-180 establishments with tightly-similar values of the index. Within each percentile, we compute the average total

\footnotetext{
${ }^{11}$ The top of Table 2 provides summary statistics for log-violation rates across establishments in the sample. Column 1 (2) presents pre-election (post-election) establishment averages and standard deviations. Column 3 presents scoring coefficients from the factor analysis. For interpretation, these coefficients imply that each establishment's violation index level in each period is measured as $0.328 * \log (1+$ average serious violations per year $)$ $+0.201 * \log (1+$ average willful violations per year $)+0.319 * \log (1+$ average repeated violations per year $)$. We use pre-election observations to estimate the factor model because the sets of establishments are more homogeneous prior to the election.
} 
number of post-election violations across the establishments. The percentile containing the mean violation-index value $(\mathrm{z}=0)$ has an average number of violations equal to 1.1 . The percentile containing the establishments with violation-indices two standard deviation above the mean $(\mathrm{z}=2)$ has an average number of violations of 10.2 violations. So, moving 2 standard deviations up from the mean is equivalent to moving up 9.1 total violations over the post-election period. In our sample, the average post-election period is 16.5 years, so one way to understand a standard deviation of the index is as 0.28 violations per post-election year. ${ }^{12}$

Fourth, to measure OSHA penalties, we use a similar approach to pool information across multiple penalty types. For each establishment in each period, after inflating penalty amounts to 2014 dollars, we measure the average annual penalties assessed of six types: \{Serious, Willful, Repeated $\}$ x \{nitial, Current $\}$. An analogous log-transformation, factor analysis, scoring, and standardization process gives pre-election and post-election penalty index levels for each establishment. ${ }^{13}$ Pre-election penalties are 12 percent of a post-election control-group standard deviation lower than the post-election control-group mean. Because violations and inspections did not change much over the same period, this suggests penalties per violation increased over time. Using the same approach as with violations to get a more conventional measure of penalties in dollar terms, note that moving up two standard deviations of the penalty index from the percentile containing $\mathrm{z}=0$ is equivalent, on average, to moving up by $\$ 62,379$ in postelection penalties. So, one standard deviation would be $\$ 1,890$ per year.

Fifth and finally, we construct an index of occupational injury risk that pools available data on the average number of workers at each establishment per year experiencing three types of occupational injuries: fatal, non-fatal but requiring hospitalization, and non-fatal and not requiring hospitalization. The motivation and approach are the same as described for violations and penalties above. The underlying OSHA data on occupational injuries is far from perfect. Dissatisfaction with OSHA's accounting for fatal occupational injuries spurred the creation of the well-regarded Census of Fatal Occupational Injuries (CFOI), which debuted in 1992. Over their shared time span, 1992 to 2011, the OSHA data contains information on about a quarter to a third of the occupational fatalities included in the CFOI (Appendix Figure 6). The bad news is

\footnotetext{
${ }^{12}$ Considering the difference between the $\mathrm{z}=0$ and $\mathrm{z}=1(\mathrm{z}=1$ and $\mathrm{z}=2)$ bins implies a difference of $3.6(5.5)$ violations, reflecting right-skew in the distribution of violations. Average these by considering a 2 SD difference. ${ }^{13}$ The middle of Table 2 provides summary statistics for log-penalty rates across establishments in the sample and the scoring coefficients obtained from the pre-election period.
} 
that our OSHA data misses a large share of injuries. The good news is that the OSHA trend moves with the CFOI trend, so it may contain some useful, if imperfect, information. We treat it as a proxy for establishments' underlying occupational injury propensity. Using the same approach as with violations and penalties to get conventional units, a one standard deviation change in the injury index can be understood as 3 reported, nonfatal or fatal injuries per 100 establishments per year. ${ }^{14}$

Use of the post-election injury index as an outcome is problematic. Suppose that unionization leads to more accurate reporting of injuries to OSHA; measurement error in the injury index is thus correlated with the treatment variable. In a regression of post-election injuries on a union-certification indicator, unionization would appear to lead to more injuries, when actually it may simply lead to higher reporting conditional on the same (or lower) injury rates. We include the analysis for completeness but do not vest it with much credibility.

\section{Control variables}

Knowing each establishment's history of OSHA inspection frequency, violations, penalties, occupational injuries, and union-representation provides a rich characterization of establishment propensity to have future inspections, violations, penalties, and injuries. For each post-election outcome variable, the most important explanatory factor conceptually is each establishment's own pre-election level on the variable, which we observe. Each establishment's own pre-election levels for the other four outcome variables also serve as predictors.

Each establishment's industry can help explain outcomes and enable more-credible, narrower comparisons. We include a set of indicators of the establishment's major industry division and construct a measure of minor industry (2-digit) occupational fatality risk using the best data available from all establishments in the U.S. economy and completely external to the OSHA data. ${ }^{15}$ We use this to characterize the relevant risk for each establishment in our sample, linking through each establishment's 2-digit SIC codes. Across establishments in our sample, the

\footnotetext{
${ }^{14}$ Moving up from the bin with $\mathrm{z}=0$ to the one with $\mathrm{z}=2$ is equivalent to moving up the average number of postelection injuries by 0.89 and $0.89 /(2 * 16.5)=0.03$.

${ }^{15}$ We measure the occupational fatality rate for each SIC2 industry each year by the ratio of a) fatal occupational injuries from the Census of Fatal Occupational Injuries (CFOI) per b) thousands of employees in the industry from the BLS Current Employment Statistics. To reduce measurement error, eleven annual rates, from 1992 to 2002, are averaged within 2 digit-SIC industries to construct a cross-section of rates across 2-digit SIC industries. This measure is based on all establishments in the U.S. economy, not just those in our sample.
} 
average minor-industry risk level is 7.61 fatalities per 100,000 full time equivalent employees (FTE) with standard deviation of 9.45. The average annual occupational fatality rate in the U.S. economy broadly fell from 5.0 in 1992 to 4.2 in 2002. Establishments in our sample, those experiencing certification elections, are in industries that are about half-again as risky as the average among all establishments. Including both of these types of industrial variables as controls implies that our analysis compares outcomes across establishments in the same industry division while controlling for differences in minor-industry risk as well as establishment-level pre-election measures of inspections, violations, penalties, labor-representation, and injuries.

\section{Analysis}

\section{Assessing validity of identifying assumption}

We present evidence from three falsification tests of the validity of the RD identifying assumption. First, there should be no discontinuity in density of vote-shares across the $50 \%$ threshold. Figure 2 presents a histogram of binned vote-shares across the sample of establishment focal NLRB elections. Most elections are close, giving a large share of the sample close to the threshold. However, we reject the null of no discontinuity in the density of vote shares across the threshold ( $\mathrm{t}=4.14)($ McCrary, 2008). This result implies a significant discontinuity in the distribution of vote-share values, raising concern about possible post-election manipulation and some degree of violation of the RD identifying condition. If we had only postelection data, violations of the RD condition would be very troubling. However, as Frandsen (2013) and Sojourner et al (2015) point out, the availability of panel data makes possible a more robust design that combines the logic of difference-in-difference and RD design.

Second, we plot how the pre-election conditional mean of each outcome variable varies as a function of vote-share bin. Consider the left-side of each of the 5 panels of Figure 3. Panel (a) displays 20 estimates of conditional mean pre-election inspection rates. The left-most estimate is the mean pre-election inspection rate for establishments that went on to have a prounion vote share between 0 and 5 percent. The 95 percent confidence interval for this conditional mean estimate is also displayed. The other 19 estimates correspond to conditional means in the other 19 vote-share bins. There does not appear to be a discontinuity in the conditional mean at the certification threshold, demarked by the vertical line. If the RDD assumption holds, there should not be. Consider the other 4 pre-election, left-side panels. In each, there is no evidence of 
a significant difference across the threshold. This is consistent with the validity of the RDD identifying conditions.

Third, we formally test for discontinuity across the threshold in the distribution of preelection observables. Close to the threshold, there should be none; farther from the threshold, there may be. ${ }^{16} \mathrm{We}$ implement the test with a seemingly-unrelated regression (SUR) model with 8 pre-election observables as dependent variables: inspection rate, labor-representative share, violations index, penalty index, and injury index, bargaining-unit size in the focal election and its square, and minor-industry (SIC 2-digit) fatality rate. Each dependent variable depends on a piecewise linear function of vote-share allowing for different intercepts and slopes on either side of the certification threshold, including a certification indicator. After estimating the SUR system, we test the joint hypothesis that the certification effects for all the dependent variables equal zero and report the $p$-value.

We perform this test in different subsamples, starting only with establishments that had vote-shares very close to the threshold and expanding the bandwidth for inclusion and, consequently, the sample incrementally. Table 3 reports the estimated discontinuity coefficients for each dependent variable, with each column reporting results from a different bandwidth. The joint null of no pre-election differences is not rejected at 5 or 10 percent significance at any bandwidth up to 0.325 (which includes focal elections with vote shares between 15-85 percent), consistent with no significant discontinuity in the distribution of pre-election characteristics and with the validity of the RD design using close elections.

\section{Union-certification effects}

To start the analysis of effects, inspect the right-side graphs in Figure 3's panels. Panel (a) plots the mean post-election inspection rate for each vote share bin. The effect of certification would appear as a discontinuous change in the conditional mean across the certification threshold. Restricting attention to establishments with close elections, there appears to be a slightly higher inspection rate where unions just won compared to where they just lost but the difference appears small in magnitude.

\footnotetext{
${ }^{16}$ A "union certification effect" prior to the election would be evidence of systematic differences leading up to the election between establishments where unions will go on to win versus where unions will go on to lose, a violation of the identifying assumption (Lee \& Lemieux (2010): Section 4.4.2; Sojourner et al (2015)).
} 
Panel (b) plots the conditional mean of labor-representative share. Here the certification effect is clear. The outcome increases smoothly with vote-share below the certification threshold and also moves relatively smoothly with vote-share above the threshold. However, there is a large, positive discontinuity apparent when the threshold is crossed. The magnitude of the effect appears to be about 0.07 . Interpreted causally, this implies that certification causes a 7 percentage point increase in the share of inspections attended by a labor representative. However, accounting for the fact that this outcome is defined only for 26 percent of the sample with any linked OSHA inspections, this could be interpreted as consistent with a 27 percent increase in union-inspection share if all establishments had been inspected. ${ }^{17}$ This result provides clear evidence that certification triggers enduring unionization.

In the other figures, effects on violations, penalties, and injuries appear small or null. Any effects appear to be generated by variations right around the threshold, particularly in the 50-55 percent bin.

To formalize this analysis and allow for controls, we use regression analysis. We estimate the effect of union certification on each outcome among establishments with NLRB election vote shares within a certain range, a bandwidth, of the certification threshold. ${ }^{18}$ For each outcome, we estimate 4 specifications, with increasingly rich sets of control variables. Table 4 displays the estimated coefficient (SE) on the won-certification indicator $(D)$ from four specifications in columns for each of the 5 outcomes, in panels from top to bottom. The top panel contains estimates of the effect of certification on establishments' annual rate of OSHA inspection. Specification 1 includes only a certification indicator and a piece-wise linear function of voteshare. The estimated certification effect (SE) is 0.00825 (0.0037), which is significant at 5 percent and has a 95 percent confidence interval of +0.001 to $+0.015 .{ }^{19}$ Specification 2 adds

\footnotetext{
${ }^{17}$ For the 74 percent of establishments with no linked OSHA records, "share of inspections attended by labor representatives" is not defined; the denominator is 0 . In these cases, we set the measured share to 0 . Because the effect of union certification in this 74 percent is 0 by construction, any observed non-zero effect of certification must be driven by the contrast among the 26 percent with linked OSHA records. To approximate the effect if all establishments experienced inspections, one might scale up the estimated effect by a factor of $3.8(=1 / 0.26)$, which implies that certification would cause a 27-percentage point increase in union-representation share. This is plausible given that only about half of certifications lead to enduring unionization (Ferguson, 2008) and not every OSHA inspection in an establishment with any union workers has a labor representative participate.

${ }^{18}$ We use local-linear regression with a uniform kernel. The bandwidth for each outcome is chosen using the optimality criterion of Imbens \& Kalyanaramang (2012).

${ }^{19}$ To save on space, this table only presents estimated coefficients for the 1 (union-certified) variable. For the outcome of inspection rate, estimates for all variables are displayed in Appendix Table 9. The estimates appears
} 
establishment pre-election inspection rate as a control variable. The establishment's own lagged outcome is a good predictor, which raises the adjusted $\mathrm{R}^{2}$ from 0.0002 to 0.057 . The estimated certification effect remains similar, $0.0086(0.0036)$. Specification 3 adds the vector of the other four lagged-outcome variables, size of the bargaining unit, and its square as controls. With these strong control variables, the estimated effect falls slightly to $0.00693(0.0035)$ but remains significant. Specification 4 adds the set of industry-division indicators and the minor-industry fatality risk measure as predictors. Because it contains the richest set of control variables, we prefer to focus on specification 4 . The estimate is similar, $0.00738(0.00347)$ with a $95 \% \mathrm{CI}$ of +0.0006 to +0.0142$]$. Taken together, this evidence is consistent positive effect of union certification on the probability of OSHA inspection such that, in 1,000 establishments at risk, unionization causes an additional 7.4 inspections per year.

To understand the magnitude, consider a few points of reference. In the private-economy broadly, about 9 establishments per 1,000 were inspected in 2014. The effect would almost double that. In the analytic sample of establishments, the mean post-election inspection rate is 30 per 1,000 with a standard deviation of 110 per 1,000 . The estimated effect is about a quarter of the mean level and about 7 percent of a standard deviation.

The second panel of panel of Table 4 presents estimates of union certification effects across basically the same four specifications on the labor-representative share. The only difference is that in specification (2), adding the lagged-outcome control here means adding lagged labor-representative share rather than adding lagged inspection rate as we did in the first panel. Across the four specifications, the estimated effect is very stable, the standard error does not rise, and adjusted $\mathrm{R}^{2}$ does. In specification (4), the estimated effect of certification on laborrepresentative share is $0.0713(0.0083)$ with a $95 \% \mathrm{CI}$ of +0.055 to +0.088 . The mean (SD) in the post-election period is $0.06(0.23)$ suggesting that the effect exceeds the mean and implies a 0.31 effect size. The estimates' stability as strong control variables are added is consistent with the validity of the research design, as in an experiment. Scaling this up by 3.8 to approximate the effect if all establishments were inspected implies a 0.27 labor-representative share effect.

sensible. For instance, the establishment's own pre-election inspection rate is strong predictor of post-election inspection rate. For the other outcomes, they are in Appendix Table 10 to Table 13. 
That is, conditional on being inspected, certification raises the probability of having a labor representative accompany the inspector by 27 percent.

The third panel reports the certification effect on the violation index. Again, the estimated effects are stable as more controls are added. In the richest specification, union certification is estimated to cause an increase in cited violations equivalent to 7.96 percent of a standard deviation with a $95 \%$ CI of +1.4 percent to +14.5 percent. Recall that increasing the violation index by a standard deviation is, on average, equivalent to having 0.28 additional violations per establishment annually in the post-election, control group. Therefore, $a+7.96$ percent of a standard deviation effect of union certification on the violation index implies an increase of 2 violations per year per 100 establishments.

The fourth panel reports the certification effect on the OSHA penalties index. Estimated effects are again stable. The richest specification yields a point estimate of +7.54 percent of a standard deviation with a $95 \%$ CI of +0.07 percent to +15.0 percent. Sensibly, this is similar in magnitude to the effect on violations. Certification causes an additional $\$ 142$ in penalties per year per establishment on average.

Finally, the fifth panel reports the estimated certification effect on the injury index. The preferred specification yields a point estimate of +12 percent of a standard deviation and $95 \% \mathrm{CI}$ of +0.0087 to +23.1 percent. Estimates are stable across specifications. This evidence is consistent with some combination of two mechanisms. Certification may actually cause more injuries, a real effect, or it may raise the probability of any injuries being reported to OSHA, a spurious result. The injury index is categorically different than the other outcomes: inspection rate, labor-representative share, violations, and penalties. These are outcomes for which the OSHA data represents a reliable and complete census. In contrast, for injuries, the OSHA data are incomplete.

\section{Robustness}

We assess the robustness of the main results to three threats to internal validity: misspecification of the longitudinal-matching algorithm to define establishments, strategic manipulation in very close elections, and alternative choices in the bias-variance tradeoff using alternative bandwidths. In all this analysis, we use the richest specification, (4), as our baseline 
and deviate from that baseline in various ways. For compactness, only the estimated unioncertification coefficient is presented in each case.

First, we assess the robustness of the main results to misspecification of the longitudinalmatching algorithm to define establishments. The whole analysis is dependent on the algorithm that we used to measure records that belong to the same establishment within and across the NLRB and OSHA datasets. Within state and industry, the matching algorithm penalizes mismatched string values in establishment name, address, and city and matches with quality above a given threshold are retained. We constructed two alternative measures of which NLRB records belong to the same establishment by varying the threshold up and down. Each defines a somewhat different set of establishments and, consequently, different set of focal elections. A more-strict, matching criterion generates fewer matches and so more unique establishments and focal elections; less strict implies fewer establishments. ${ }^{20}$ Consequently, all variables defined at the establishment level vary somewhat. Table 5 presents estimates based on two alternative match-quality thresholds, along with baseline estimates. Across all outcomes, results are stable.

Second, a recent working paper reports evidence that, in very close elections, postelection legal maneuvering may undermine the key identifying assumption of the RDD (Frandsen, 2013). In the elections with the narrowest margins of victory (the smallest difference between the number of pro-union votes cast and the number of pro-union votes necessary for the union to win certification), incentives for manipulation are strongest and there is compelling evidence that management and unions are able to manipulate final vote counts in the elections with the narrowest margins of victory (MOV). As discussed earlier and displayed in Figure 2, evidence from the McCrary test is consistent with this kind of violation in our data. To deal with this, in the main analysis, we exploit the panel nature of the data by conditioning on pre-election lagged outcomes and covariates. Here, we use a second approach. Because concern about manipulation is greater when MOV is smaller, we use a donut-RD approach (Barreca, Guldi, Lindo, \& Waddell, 2011), excluding establishments with the smallest MOV and assessing how results change. Table 6 displays the results. The first column displays our baseline results for comparison. The second column excludes establishments where the outcome of the focal election could have been changed if 1 vote switched sides. The third and fourth columns exclude

\footnotetext{
${ }^{20}$ The more-strict, baseline, and less-strict criterion imply 31,151, 31,052, and 30,728 unique establishments, respectively.
} 
those elections where a switch of 2 and 3 votes, respectively, could change the outcome. ${ }^{21}$ As these more-questionable cases are excluded, how do estimates change? The estimated effect on inspection rate and penalties are stable but lose significance. The estimated effects on laborrepresentative share and violations rise in magnitude and maintain significance. The estimated effect on injuries immediately falls basically to zero and loses significance.

\section{Heterogeneity in effects}

OSHA conducts two types of inspections: programmed and complaint-initiated.

Programmed inspections depend on establishment characteristics other than unionization status and are scheduled centrally by OSHA staff looking across the whole universe of establishments. If analysis found a large effect of union certification on programmed inspection rates, it would be a red flag that the design is flawed, though increased exercise of walkaround rights during programmed inspections could lead to additional violations and penalties. Worker, union, or others' complaints or reported accidents trigger these non-programmed inspections. Union certification should have effects on inspection rates via complaint-initiated inspections. To check whether mechanisms are operating as expected, two separate versions of each outcome are constructed, one based solely on programmed inspections and the other on complaint-initiated ones. ${ }^{22}$ Union certification effects are estimated on each. Table 7 displays results. ${ }^{23}$ First, the effect of certification on inspection rate operates completely through complaint-initiated inspections, as expected. Second, there are significant increases in the exercise of walkaround rights in both types of inspections, consistent with certification leading to unionization which increases general labor representation in the enforcement process. The effect is stronger for complaint-initiated inspections, consistent with unionization driving these reports. There is weak evidence of an increase in violations and penalties during programmed inspections and strong evidence for increases during complaint-initiated ones. Labor representation leads to stricter enforcement. Finally, certification leads to increased injury reporting via complaint-initiated inspections.

\footnotetext{
${ }^{21}$ Sample size drops rapidly because we are losing most of the small elections; if they have a large MOV, they must not be close. If they are close, they must have a small MOV.

${ }^{22}$ To keep units stable, Table 2 scoring coefficients are used to construct penalty, violation, and injury indices.

${ }^{23}$ There are generally no injuries in programmed inspections so we cannot construct measures there.
} 
In different settings, both Weil and Morantz looked at the effects of unionization on enforcement activity by establishment size and reached different conclusions. We want to extend that analysis to our sample. We rank all establishments by the size of the bargaining unit in the focal NLRB election and split the sample into thirds, or terciles. ${ }^{24}$ Then, we estimate the baseline specification (Table 4: Specification 4) in each tercile for each outcome. The resulting unioncertification effect estimates are presented in the 5 panels of Figure 4 . The labor-representative share increases significantly in all terciles, though only about half as much in smaller establishments as in the middle and top thirds (Panel b). For the enforcement outcomes (Panels a, c, d), there is no evidence of effects in the smallest establishments. In contrast, the point estimates suggest that any effect of certification on injuries appears shows up in stronger in smaller establishments, though the effect is not significant in any tercile alone. Certification effects on enforcement intensity are stronger in establishments where injury effects appear weaker (and vice-versa).

\section{Conclusion}

Union victory in close NLRB certification elections leads to increased occupationalsafety law-enforcement activity and increased worker representation in the enforcement process. Union certification increases OSHA activity - inspection rates, violations cited, and penalties assigned - each by about 8 percent of a standard deviation. The results are remarkably consistent across outcomes. Further, conditional on having an OSHA inspection, union certification increases the share of inspections that have a labor representative participating by 27 percentage points. This provides the strongest evidence in the literature documenting a rights-facilitation effect of unions. These results imply that falling unionization rates nationally are reducing workers' exercise of their rights to participate in the occupational safety enforcement process and weakening a private actor that co-produces law enforcement along with agency staff.

Despite union effects in increasing OSHA enforcement activity, we do not see evidence of a substantial reduction in occupational injury though we have access only to a flawed measure of injuries. ${ }^{25}$ This result is consistent with two basic interpretations. On its face, a naïve

\footnotetext{
${ }^{24}$ The small (medium) (large) third includes 10,286 (10,370) $(10,396)$ establishments with bargaining units sized 20-41 (42-86) (87-17,195).

${ }^{25}$ Research has produced strong evidence of unions reducing fatal occupational injuries in mining historically (Boal, 2009) and recently (Morantz A. , 2012). However, evidence from other settings has been mixed. Boal writes,
} 
interpretation suggests that increased enforcement activity does not increase safety and that the marginal enforcement activity is wasteful. However, other interpretations merit consideration. First, there may a real effect of unionization in increasing injury risk. Suppose unionization raises hourly pay and fringe benefits and management responds to this pressure on profits by seeking to reduce costs on other margins, including reducing job safety (Fairris, 1995). In that case, OSHA may become more active either on its own or via increased worker and union reporting. We would observe a positive effect of unionization on OSHA enforcement activity. These enforcement efforts may succeed in holding the line on safety levels, producing a null effect on safety. That is, the enforcement activity may raise safety above what would have been observed if workers unionized, got raises, and did not have recourse to OSHA. However, in this case, we would expect to see positive effects on enforcement activity and reported injuries being stronger in the same subsamples, which we do not. The enforcement effect is stronger in larger establishments, where the effect on reported injuries is weaker. Second, unionization may raise the likelihood each injury is reported to OSHA. Even if unionization causes injury rates to fall, it may also cause reported injuries to rise. If underreporting were especially severe in smaller, nonunion establishments relative to larger, nonunion establishments, then unionization might produce larger effects on reported injuries in smaller establishments, consistent with the observed evidence.

Because the prior literature has shown that only about half of certifications lead to first contracts and stable unions, one may want to think of the unionization effect as double these certification effects. Though the baseline rates of OSHA inspection activity are very low -only about a quarter of the establishments see any inspection activity over 27 years - our large sample size and measurement strategy yields enough leverage to get very precise estimates.

Our result that unionization increases enforcement activity are qualitatively consistent with the results of Weil (1991) and Morantz (2011) but derive from different evidence in important ways. First, our sample looks across all private-sector industries and across all years from 1985 to 2011. Second, we are better able to separate causal effects from associated omitted-

\footnotetext{
"Studies of unionism and occupational safety are surprisingly few and disappointingly inconclusive." Morantz makes a related point, "The empirical literature on the relationship between unionization and workplace safety presents a curious puzzle. On the one hand, scholars have documented numerous ways unions help to promote safe work practices.... Yet most empirical studies of the relationship between unionization and important safety outcomes, such as injuries and fatalities, have failed to find statistically significant evidence of a 'union safety effect." "We add to this body of work.
} 
variables through strong research design drawing on establishment-level panel data. Third, we estimate the local average treatment effect across the certification threshold rather than an average treatment effect for union versus non-union broadly. However, these results strengthen the credibility of their conclusions and extends the domain of knowledge from manufacturing in 1985 and mining to basically the whole U.S. private economy between 1985 and 2014. This study also puts a stronger evidence base under Weil's finding that union effects on OSHA enforcement intensity are bigger in larger than in smaller establishments. This contrasts with Morantz's result from study of MSHA enforcement in mining, where union effects were bigger in smaller establishments. MSHA and OSHA differ in many respects. Obviously, they differ in industries covered. They also differ in baseline enforcement intensity. For instance, OSHA and state partners carry out approximately 0.9 inspections per 100 establishments annually. In contrast, MSHA must inspect every establishment at least four times annually (Morantz A. , 2011), implying an inspection rate over 400 higher than OSHA's. There may be little scope for unions to increase enforcement intensity in large mines and, so, effects may show up more in smaller ones. However, outside mining, plenty of scope exists for unions to increase OSHA enforcement intensity at all kinds of establishments. Here, larger effects in larger establishments may occur because any hazard affects more workers in a larger establishment and this may trigger a greater willingness to invest in monitoring in larger establishments on the part of unionized workers, union staff, and OSHA staff. 


\section{Bibliography}

Barreca, A., Guldi, M., Lindo, J., \& Waddell, G. (2011). Saving Babies? Revisiting the Effect of Very Low Birth Weight Classification. Quarterly Journal of Economics, 126(4), 21172123.

Boal, W. (2009). The Effect of Unionism on Accidents in U.S. Coal Mining, 1897-1929. Industrial Relations, 48(1), 97-120.

Budd, J., \& McCall, B. (1997). The Effect of Unions on the Reciept of Unemployment Insurance Benefits. Industrial and Labor Relations Review, 50(3), 478-492.

DiNardo, J., \& Lee, D. (2004). Economic impacts of new unionization on private sector employers: 1984-2001. Quarterly Journal of Economics, 119(4), 1382-1441.

DiNardo, J., \& Lee, D. (2011). Program Evaluation and Research Design. In Handbook of Labor Economics (Vol. 4a, pp. 465-536). Elsevier.

Ferguson, J.-P. (2008). Eyes of the Needles: A Sequential Model of Union Organizing Drives, 1999-2004. Industrial and Labor Relations Review, 62(3), 3-21.

Frandsen, B. (2012). Why Unions Still Matter: The Effects of Unionization on the Distribution of Employee Earnings. Cambridge, Mass.: Massachusetts Institute of Technology manuscript.

Frandsen, B. (2013). The Surprising Impacts of Unionization on Establishments: Accounting for Selection in Close Union Representation Elections. Provo, Utah: Brigham Young University manuscript.

Freeman, R., \& Kleiner, M. (1999). Do Unions Make Enterprises Insolvent? Industrial and Labor Relations Review, 52(4), 510.

Holmes, T. (2006). Geographic Spillover of Unionism. Cambridge, Mass.: National Bureau of Economic Research Working Paper \#12025.

Imbens, G., \& Kalyanaramang, K. (2012). Optimal Bandwidth Choice for the Regression Discontinuity Estimator. Review of Economic Studies, 79(3), 933-959.

Lee, D., \& Lemieux, T. (2010). Regression Discontinuity Designs in Economics. Journal of Economic Literature, 48, 281-355.

Lee, D., \& Mas, A. (2012). Long-run impacts of unions on firms: New evidence from financial markets, 1961-1999. Quarterly Journal of Economics, 127(1), 333-378.

McCrary, J. (2008). Manipulation of the running variable in the regression discontinuity design: a density test. Journal of Econometrics, 142(2), 698-714. 
Morantz, A. (2011). Does Unionization Strengthen Regulatory Enforcement? An Empirical Study of the Mine Safety and Health Administration. Journal of Legislation and Public Policy, 14, 697-727.

Morantz, A. (2012). Coal Mine Safety: Do Unions Make A Difference? Industrial and Labor Relations Review, 66(1), 88-116.

Smith, R. S. (1986). Greasing the Squeaky Wheel: The Relative Productivity of OSHA Complaint Inspections. Industrial and Labor Relations Review, 40(1), 35-47.

Sojourner, A., Frandsen, B., Town, R., Grabowski, D., \& Chen, M. (2015). Impacts of Unionization on Employment, Product Quality, and Productivity: Regression Discontinuity Evidence from Nursing Homes. Industrial and Labor Relations Review, 68(4), 771-806.

U.S. Department of Labor. (2014, January). Dataset Summary. Retrieved January 2014, from OSHA Enforcement Data: http://ogesdw.dol.gov/views/data_summary.php

Weil, D. (1991). Enforcing OSHA: The Role of Unions. Industrial and Labor Relations Review, 30(1), 20-36. 


\section{Tables}

Table 1: Summary statistics

\begin{tabular}{l|rrrr}
\hline Variable & Mean & Std. Dev. & Min & Max \\
\hline Vote share & & & & \\
Eligible voters & 0.49 & 0.23 & 0.0 & 1.00 \\
& 107.06 & 212.47 & 20 & 17195 \\
Post-election & & & & \\
Inspection rate & & & & \\
Labor-representative share & 0.03 & 0.11 & 0.00 & 6.28 \\
Violation index & 0.06 & 0.23 & 0.00 & 1.00 \\
Penalty index & -0.006 & 1.05 & -0.24 & 50.78 \\
Injury index & -0.006 & 1.03 & -0.27 & 20.18 \\
& 0.01 & 1.35 & -0.08 & 121.84 \\
Pre-election & & & & \\
Inspection rate & & & & \\
Labor-representative share & 0.04 & 0.21 & 0.00 & 12.00 \\
Violation index & 0.02 & 0.15 & 0.0 & 1.00 \\
Penalty index & -0.03 & 1.34 & -0.24 & 71.06 \\
Injury index & -0.12 & 0.73 & -0.27 & 22.58 \\
& 0.02 & 2.53 & -0.08 & 220.55 \\
Average fatality rate in 2-digit SIC & & & & \\
\hline
\end{tabular}

Notes: for each variable, these are summary statistics across the 31,052 establishments meeting sample inclusion criteria. 
Table 2: Summary statistics for OSHA variables and factor construction

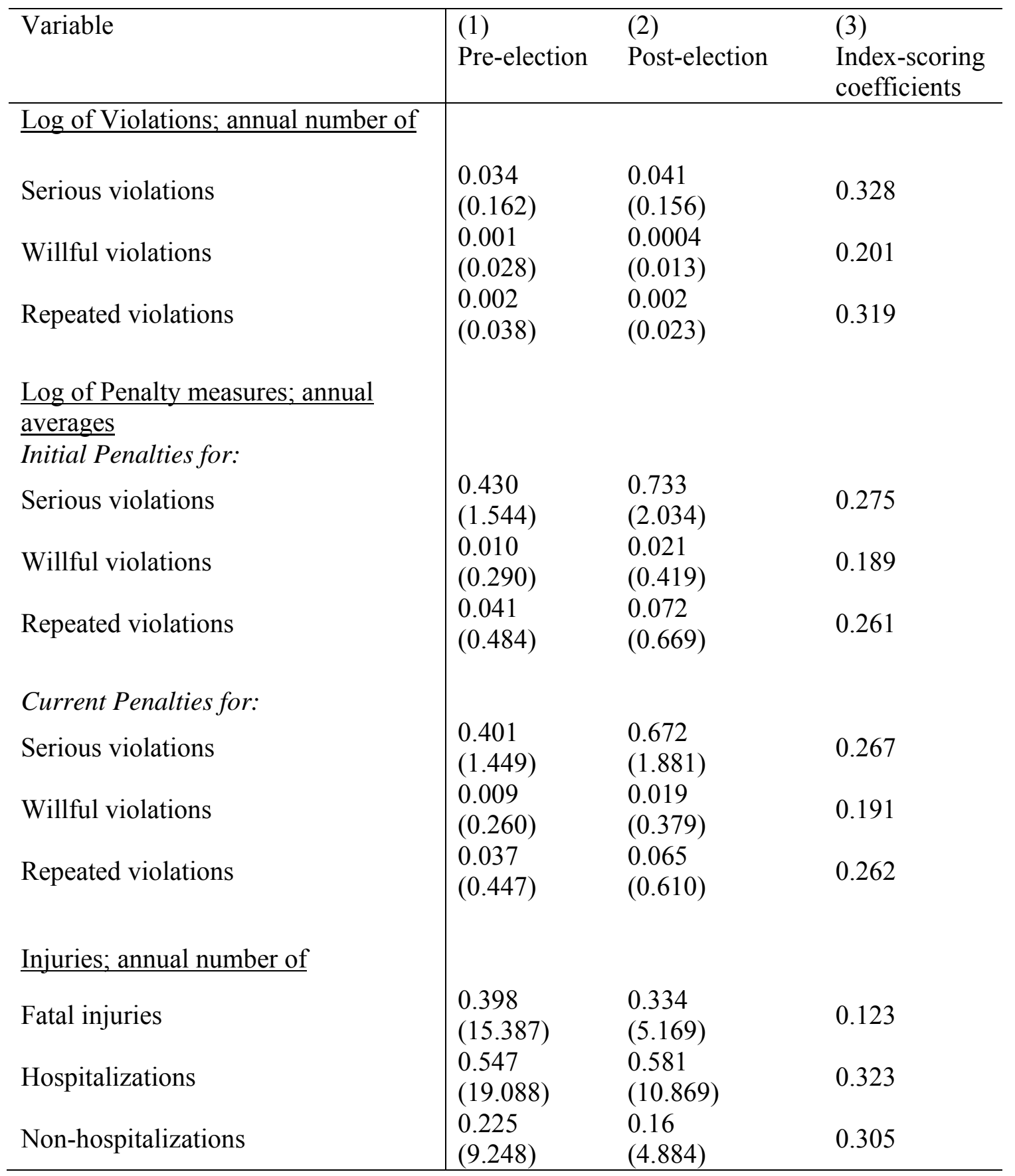

Notes: Annual rates of violations and penalties were calculated by dividing each count by number of years. The number of observation of each variable is 31,052 . 
Table 3: Coefficients on union certified in Seemingly Unrelated Regression at varied bandwidth

\begin{tabular}{|c|c|c|c|c|c|c|c|c|}
\hline $\begin{array}{l}\text { Specification: } \\
\text { Bandwidth: } \\
\text { Vote-share range included: } \\
\text { Pre-election observables }\end{array}$ & $\begin{array}{l}(1) \\
0.025 \\
(45,55] \%\end{array}$ & $\begin{array}{l}(2) \\
0.075 \\
(40,60] \%\end{array}$ & $\begin{array}{l}(3) \\
0.125 \\
(35,65] \%\end{array}$ & $\begin{array}{l}(4) \\
0.175 \\
(30,70] \%\end{array}$ & $\begin{array}{l}(5) \\
0.225 \\
(25,75] \%\end{array}$ & $\begin{array}{l}(6) \\
0.275 \\
(20,80] \%\end{array}$ & $\begin{array}{l}(7) \\
0.325 \\
(15,85] \%\end{array}$ & $\begin{array}{l}(8) \\
0.375 \\
(10,90] \%\end{array}$ \\
\hline Pre-election inspection rate & $\begin{array}{l}-0.000148 \\
(0.00478)\end{array}$ & $\begin{array}{l}0.00667 \\
(0.00972)\end{array}$ & $\begin{array}{l}-0.00318 \\
(0.00782)\end{array}$ & $\begin{array}{l}-0.00542 \\
(0.00656)\end{array}$ & $\begin{array}{l}-0.00542 \\
(0.00585)\end{array}$ & $\begin{array}{l}-0.00864 \\
(0.00522)\end{array}$ & $\begin{array}{l}-0.00652 \\
(0.00479)\end{array}$ & $\begin{array}{l}-0.00370 \\
(0.00451)\end{array}$ \\
\hline Pre-election union-rep share & $\begin{array}{l}0.00599 \\
(0.00410)\end{array}$ & $\begin{array}{l}0.00293 \\
(0.00654)\end{array}$ & $\begin{array}{l}0.00661 \\
(0.00497)\end{array}$ & $\begin{array}{l}0.00715 \\
(0.00419)\end{array}$ & $\begin{array}{l}0.00627 \\
(0.00378)\end{array}$ & $\begin{array}{l}0.00607 \\
(0.00340)\end{array}$ & $\begin{array}{l}0.00639 * \\
(0.00315)\end{array}$ & $\begin{array}{l}0.00553 \\
(0.00302)\end{array}$ \\
\hline Pre-election violations index & $\begin{array}{l}0.0388 \\
(0.0498)\end{array}$ & $\begin{array}{l}0.0796 \\
(0.0726)\end{array}$ & $\begin{array}{l}0.0128 \\
(0.0581)\end{array}$ & $\begin{array}{l}0.0298 \\
(0.0464)\end{array}$ & $\begin{array}{l}0.0296 \\
(0.0403)\end{array}$ & $\begin{array}{l}0.0250 \\
(0.0359)\end{array}$ & $\begin{array}{l}0.0256 \\
(0.0335)\end{array}$ & $\begin{array}{l}0.0237 \\
(0.0314)\end{array}$ \\
\hline Pre-election penalty index & $\begin{array}{l}0.0244 \\
(0.0233)\end{array}$ & $\begin{array}{l}0.0414 \\
(0.0357)\end{array}$ & $\begin{array}{l}0.0168 \\
(0.0282)\end{array}$ & $\begin{array}{l}0.0377 \\
(0.0237)\end{array}$ & $\begin{array}{l}0.0328 \\
(0.0211)\end{array}$ & $\begin{array}{l}0.0191 \\
(0.0191)\end{array}$ & $\begin{array}{l}0.0187 \\
(0.0177)\end{array}$ & $\begin{array}{l}0.0152 \\
(0.0167)\end{array}$ \\
\hline Pre-election injury index & $\begin{array}{l}-0.0360 \\
(0.0418)\end{array}$ & $\begin{array}{l}-0.0269 \\
(0.0712)\end{array}$ & $\begin{array}{l}-0.0246 \\
(0.0839)\end{array}$ & $\begin{array}{l}-0.108 \\
(0.0830)\end{array}$ & $\begin{array}{l}-0.0710 \\
(0.0701)\end{array}$ & $\begin{array}{l}-0.0951 \\
(0.0685)\end{array}$ & $\begin{array}{l}-0.0659 \\
(0.0616)\end{array}$ & $\begin{array}{l}-0.0317 \\
(0.0587)\end{array}$ \\
\hline Eligible voters & $\begin{array}{l}1.616 \\
(6.029)\end{array}$ & $\begin{array}{l}6.336 \\
(8.420)\end{array}$ & $\begin{array}{l}14.22 \\
(7.313)\end{array}$ & $\begin{array}{l}9.746 \\
(6.061)\end{array}$ & $\begin{array}{l}4.530 \\
(5.383)\end{array}$ & $\begin{array}{l}-2.273 \\
(4.895)\end{array}$ & $\begin{array}{l}-5.511 \\
(5.157)\end{array}$ & $\begin{array}{l}-11.24 * \\
(4.788)\end{array}$ \\
\hline Eligible voters squared & $\begin{array}{l}17867.3 \\
(17753.7)\end{array}$ & $\begin{array}{l}29865.2 \\
(20447.0)\end{array}$ & $\begin{array}{l}43914.1 \\
(41673.8)\end{array}$ & $\begin{array}{l}20061.6 \\
(31627.1)\end{array}$ & $\begin{array}{l}3792.9 \\
(26253.4)\end{array}$ & $\begin{array}{l}1244.9 \\
(23575.5)\end{array}$ & $\begin{array}{l}33254.2 \\
(47978.3)\end{array}$ & $\begin{array}{l}17283.3 \\
(44209.8)\end{array}$ \\
\hline Average fatality rate in SIC2 & $\begin{array}{l}0.0236 \\
(0.282)\end{array}$ & $\begin{array}{l}0.222 \\
(0.447)\end{array}$ & $\begin{array}{l}0.251 \\
(0.343)\end{array}$ & $\begin{array}{l}-0.0755 \\
(0.291)\end{array}$ & $\begin{array}{l}-0.177 \\
(0.261)\end{array}$ & $\begin{array}{l}-0.0777 \\
(0.240)\end{array}$ & $\begin{array}{l}-0.0736 \\
(0.224)\end{array}$ & $\begin{array}{l}0.00631 \\
(0.213)\end{array}$ \\
\hline Observations & 4,318 & 9,237 & 13,830 & 18,053 & 21,513 & 24,420 & 26,592 & 28,205 \\
\hline$\chi^{2}$ & 6.40 & 4.39 & 7.29 & 12.06 & 9.87 & 12.06 & 16.03 & 19.93 \\
\hline$p$-value & 0.6021 & 0.8202 & 0.5053 & 0.1487 & 0.2743 & 0.1486 & 0.0419 & 0.0106 \\
\hline
\end{tabular}

Note: Estimate (SE). ***Significant at the $1 \%$ level, **Significant at the $5 \%$ level, *Significant at the $10 \%$ level. All estimates show coefficients for 1 (union certified) in seemingly unrelated regressions. $\chi^{2}$ and $p$-value are from the joint hypothesis test of null discontinuity effects across all pre-election variables. 
Table 4: Effects of union certification on various outcomes with piece-wise linear function of vote share using uniform kernel with IK-optimal bandwidth for each outcome

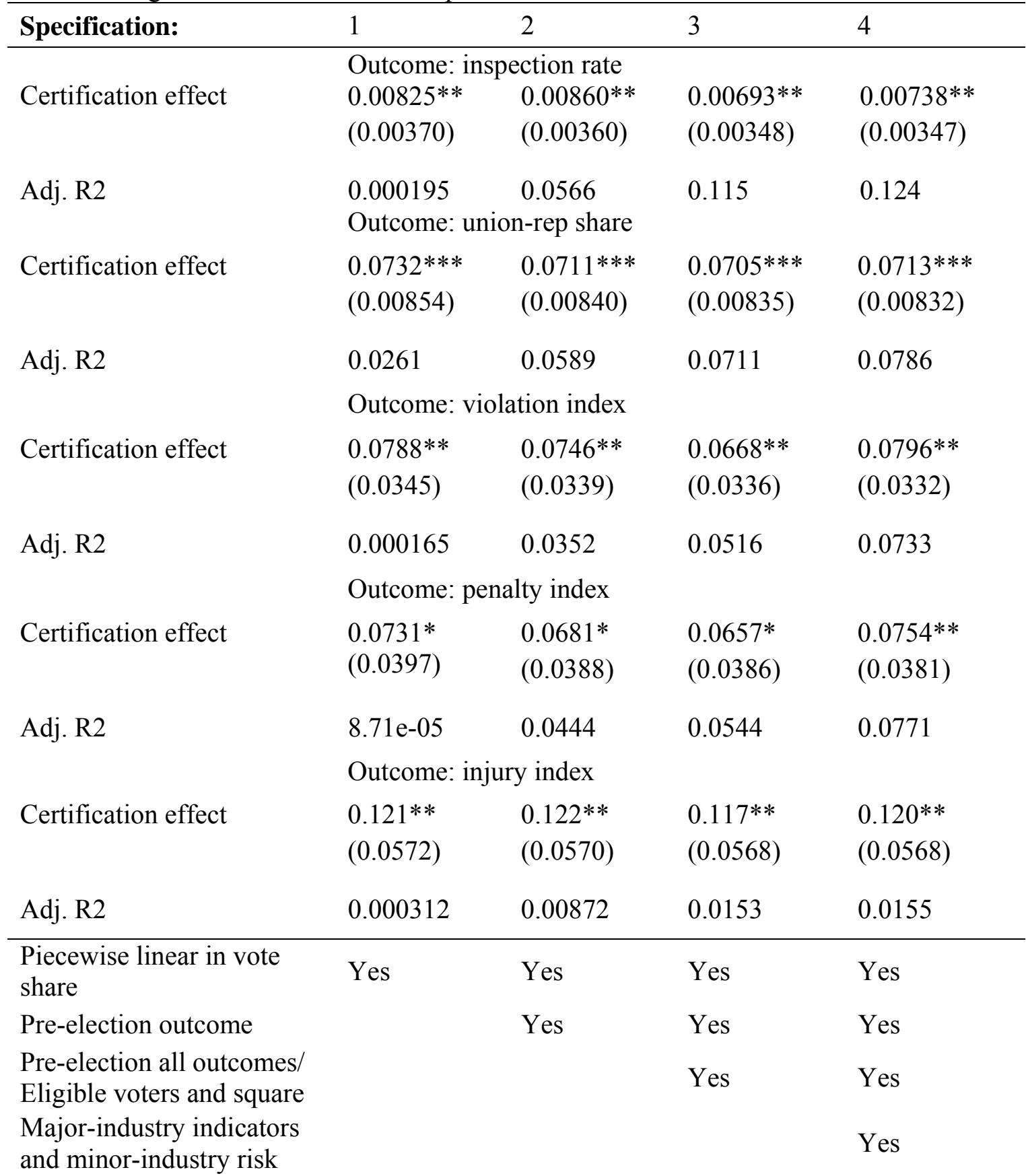

Notes: Estimate (SE). Significant at $* * * 1 \%, * * 5 \%, * 10 \%$ level. This displays estimated union certification effects on 5 outcomes (rows) using four specifications (columns) each. The full set of coefficient estimates for all variables and all specifications for the five outcomes are in Appendix Tables A6(a)- A6(e). The IK-optimal bandwidths for the outcomes are $0.128,0.196,0.153,0.151$, and 0.146 , respectively. Given the definition of vote share into $5 \%$ bins, effective bandwidths are 0.175 for optimal bandwidth in $(0.125,0.175]$ and 0.225 for the one in $(0.175,0.225]$ implying 13,830 and 18,053 establishments included, respectively. 
Table 5: Effects of union certification by strictness of matching-algorithm used to construct establishment panel

\begin{tabular}{|c|c|c|c|}
\hline Matching algorithm: & More strict & Baseline & Less strict \\
\hline & \multicolumn{3}{|c|}{ Outcome: inspection rate } \\
\hline Certification effect & $\begin{array}{l}0.00748 * * \\
(0.00346)\end{array}$ & $\begin{array}{l}0.00738 * * \\
(0.00347)\end{array}$ & $\begin{array}{l}0.00675^{*} \\
(0.00345)\end{array}$ \\
\hline Adj. $R^{2}$ & 0.123 & 0.124 & 0.114 \\
\hline \multirow[t]{2}{*}{ Obs. } & 13,871 & 13,830 & 13,678 \\
\hline & \multicolumn{3}{|c|}{ Outcome: union-representative share } \\
\hline Certification effect & $\begin{array}{l}0.0712 * * * \\
(0.00826)\end{array}$ & $\begin{array}{l}0.0713 * * * \\
(0.00832)\end{array}$ & $\begin{array}{l}0.0740 * * * \\
(0.00836)\end{array}$ \\
\hline Adj. $R^{2}$ & 0.0770 & 0.0786 & 0.0776 \\
\hline \multirow[t]{2}{*}{ Obs. } & 13,871 & 13,830 & 13,678 \\
\hline & \multicolumn{3}{|c|}{ Outcome: violation index } \\
\hline Certification effect & $\begin{array}{l}0.0856^{* *} \\
(0.0334)\end{array}$ & $\begin{array}{l}0.0796 * * \\
(0.0332)\end{array}$ & $\begin{array}{l}0.0801 * * \\
(0.0335)\end{array}$ \\
\hline Adj. $R^{2}$ & 0.0737 & 0.0733 & 0.0712 \\
\hline \multirow[t]{2}{*}{ Obs. } & 18,110 & 18,053 & 17,856 \\
\hline & \multicolumn{3}{|c|}{ Outcome: penalty index } \\
\hline Certification effect & $\begin{array}{l}0.0782 * * \\
(0.0382)\end{array}$ & $\begin{array}{l}0.0754 * * \\
(0.0381)\end{array}$ & $\begin{array}{l}0.0778 * * \\
(0.0388)\end{array}$ \\
\hline Adj. $\mathrm{R}^{2}$ & 0.0758 & 0.0771 & 0.0755 \\
\hline \multirow[t]{2}{*}{ Obs. } & 13,871 & 13,830 & 13,678 \\
\hline & \multicolumn{3}{|c|}{ Outcome: injury index } \\
\hline Certification effect & $\begin{array}{l}0.120 * * \\
(0.0566)\end{array}$ & $\begin{array}{l}0.120 * * \\
(0.0568)\end{array}$ & $\begin{array}{l}0.113 * * \\
(0.0535)\end{array}$ \\
\hline Adj. $\mathrm{R}^{2}$ & 0.0155 & 0.0155 & 0.0210 \\
\hline Obs. & 13,871 & 13,830 & 13,678 \\
\hline
\end{tabular}

Note: Estimate (SE). Significant at $* * * 1 \%, * * 5 \%, * 10 \%$ level. Establishments were matched using three different matching algorithms by strictness. All estimates based on specification (4) in Table 4. Baseline results are in the middle column (strgroup threshold 0.25). These are compared to results based on using stricter (0.2) and less strict (0.3) criterion. The total number of observations for all bandwidth for stricter criterion is 31,151 , and 30,728 for less strict criterion. The IK-optimal bandwidths for the outcomes of stricter criteria are $0.133,0.156,0.189,0.140$, and 0.149 , respectively. Also, IK-optimal bandwidths for the outcomes of less strict criteria are $0.133,0.161,0.206,0.151$, and 0.141 respectively. 
Table 6: Effects of union certification using donut-RD, with various criteria for excluding based on margin of victory (MOV)

\begin{tabular}{|c|c|c|c|c|}
\hline Sample: & Baseline & $\begin{array}{l}\text { Excluding } \\
\text { MOV } \leq 1\end{array}$ & $\begin{array}{l}\text { Excluding } \\
\text { MOV } \leq 2\end{array}$ & $\begin{array}{l}\text { Excluding } \\
\text { MOV } \leq 3\end{array}$ \\
\hline Certification effect & $\begin{array}{l}\text { Outcome: } \\
0.00738 * * \\
(0.00347)\end{array}$ & $\begin{array}{l}\text { ection rate } \\
0.00541 \\
(0.00490)\end{array}$ & $\begin{array}{l}0.00613 \\
(0.00584)\end{array}$ & $\begin{array}{l}0.00706 \\
(0.00714)\end{array}$ \\
\hline Adj. $R^{2}$ & 0.124 & 0.112 & 0.119 & 0.131 \\
\hline Obs. & 13,830 & 11,180 & 9,335 & 7,505 \\
\hline Certification effect & $\begin{array}{l}\text { Outcome: } \\
0.0713 * * * \\
(0.00832)\end{array}$ & $\begin{array}{l}\text { r-representa } \\
0.0898 * * * \\
(0.0113)\end{array}$ & $\begin{array}{l}\text { share } \\
0.110 * * * \\
(0.0137)\end{array}$ & $\begin{array}{l}0.125 * * * \\
(0.0162)\end{array}$ \\
\hline Adj. $R^{2}$ & 0.0786 & 0.0865 & 0.0897 & 0.0932 \\
\hline \multirow[t]{2}{*}{ Obs. } & 13,830 & 11,180 & 9,335 & 7,505 \\
\hline & \multicolumn{4}{|c|}{ Outcome: violation index } \\
\hline Certification effect & $\begin{array}{l}0.0796 * * \\
(0.0332)\end{array}$ & $\begin{array}{l}0.0978 * * \\
(0.0441)\end{array}$ & $\begin{array}{l}0.123^{* *} \\
(0.0533)\end{array}$ & $\begin{array}{l}0.147 * * \\
(0.0619)\end{array}$ \\
\hline Adj. $R^{2}$ & 0.0733 & 0.0704 & 0.0666 & 0.0662 \\
\hline Obs. & 18,053 & 15,403 & 13,558 & 11,546 \\
\hline Certification effect & $\begin{array}{l}\text { Outcome: } 1 \\
0.0754^{* *} \\
(0.0381)\end{array}$ & $\begin{array}{l}\text { lty index } \\
0.123^{* *} \\
(0.0539)\end{array}$ & $\begin{array}{l}0.146^{* *} \\
(0.0677)\end{array}$ & $\begin{array}{l}0.120 \\
(0.0789)\end{array}$ \\
\hline Adj. $R^{2}$ & 0.0771 & 0.0777 & 0.0751 & 0.0774 \\
\hline Obs. & 13,830 & 11,180 & 9,335 & 7,505 \\
\hline Certification effect & $\begin{array}{l}\text { Outcome: } \\
0.120^{* *} \\
(0.0568)\end{array}$ & $\begin{array}{l}y \text { index } \\
-0.0233 \\
(0.0483)\end{array}$ & $\begin{array}{l}-0.0224 \\
(0.0495)\end{array}$ & $\begin{array}{l}0.0223 \\
(0.0500)\end{array}$ \\
\hline Adj. $R^{2}$ & 0.0155 & 0.0319 & 0.00502 & 0.00655 \\
\hline Obs. & 13,830 & 11,180 & 9,335 & 7,505 \\
\hline
\end{tabular}

Note: Estimate (SE). Significant at $* * * 1 \%, * * 5 \%,{ }^{*} 10 \%$ level. Each cell presents estimated union certification effect as in specification (4) in Table 4. Baseline results are in the first column. Other columns report estimates from samples excluding establishments with focal elections that have margins of victory below the stated thresholds. 
Table 7: Effects of union certification by inspection type

\begin{tabular}{lccccc}
\hline Outcome: & Inspection rate & $\begin{array}{c}\text { Labor-rep. } \\
\text { share }\end{array}$ & Violation & Penalty & Injury \\
\hline Programmed & & & & & \\
Certification effect & -0.000188 & $0.0302^{* * *}$ & 0.0460 & $0.0926^{*}$ & $\mathrm{n} / \mathrm{a}$ \\
& $(0.00160)$ & $(0.00593)$ & $(0.0364)$ & $(0.0540)$ & \\
Optimal bandwidth & 0.129 & 0.158 & 0.132 & 0.112 & \\
Adj. $\mathrm{R}^{2}$ & 0.0575 & 0.0382 & 0.0451 & 0.0333 & \\
Obs. & 13,830 & 13,830 & 13,830 & 9,237 &
\end{tabular}

\section{Complaint-initiated}

$\begin{array}{lccccc}\text { Certification effect } & 0.00751^{* * *} & 0.0638^{* * *} & 0.0868^{*} & 0.0669 * * & 0.119^{* *} \\ & (0.00275) & (0.00756) & (0.0457) & (0.0292) & (0.0569) \\ \text { Optimal bandwidth } & 0.145 & 0.152 & 0.154 & 0.249 & 0.147 \\ \text { Adj. } \mathrm{R}^{2} & 0.106 & 0.0666 & 0.0461 & 0.0584 & 0.0155 \\ \text { Obs. } & 13,830 & 13,830 & 13,830 & 21,513 & 13,830\end{array}$

Note: Estimate (SE). ${ }^{* * *}$ Significant at the $1 \%$ level, ${ }^{* *}$ Significant at the $5 \%$ level, $*$ Significant at the $10 \%$ level. Note: All estimates based on specification (4) in Table 4. No injuries in programmed inspections. 


\section{Figures}

Figure 1: Example of OSHA enforcement data for a particular inspection

UNITED STATES

DEPARTMENT OF LABOR

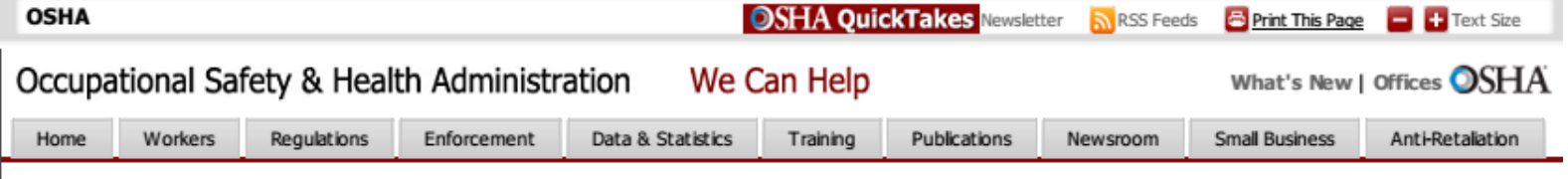

Inspection: 316563352 - Ace Acme Septic Service Inc

Inspection Information - Office: Washington Region 1

\begin{tabular}{|c|c|c|}
\hline \multicolumn{3}{|c|}{ Inspection Information - Office: Washington Region 1} \\
\hline Nr: 316563352 & Report ID: 1055310 & Open Date: 11/20/2012 \\
\hline \multicolumn{3}{|l|}{ Ace Acme Septic Service Inc } \\
\hline $\begin{array}{l}17924 \text { 67th Ave } \mathrm{Ne} \\
\text { Arlington, WA } 98223\end{array}$ & & Union Status: NonUnion \\
\hline \multicolumn{3}{|c|}{$\begin{array}{l}\text { SIC: 7699/Repair Shops and Related Services, Not Elsewhere Classified } \\
\text { NAICS: 562991/Septic Tank and Related Services }\end{array}$} \\
\hline \multicolumn{3}{|l|}{ Inspection Type: Referral } \\
\hline Scope: Partial & & Advanced Notice: $\mathrm{N}$ \\
\hline \multicolumn{3}{|l|}{ Ownership: Private } \\
\hline \multirow[t]{2}{*}{ Safety/Health: Health } & & Close Conference: $12 / 11 / 2012$ \\
\hline & & Close Case: 05/21/2013 \\
\hline \multirow{2}{*}{$\begin{array}{r}\text { Related Activity: Type } \\
\text { Referral }\end{array}$} & ID Safety & Health \\
\hline & 203171350 & Yes \\
\hline
\end{tabular}

\begin{tabular}{|r|r|r|r|r|r|r|}
\hline & \multicolumn{5}{|c|}{ Violation Summary } \\
\hline & Serious & Wilful & Repeat & Other & Unclass & Total \\
\hline Intial Violations & 5 & & & 6 & & 11 \\
\hline Current Violations & 5 & & & 6 & & 11 \\
\hline Initial Penalty & 1500 & & & & & 1500 \\
\hline Current Penalty & 1500 & & & & & 1500 \\
\hline FTA Amount & & & & & & \\
\hline
\end{tabular}

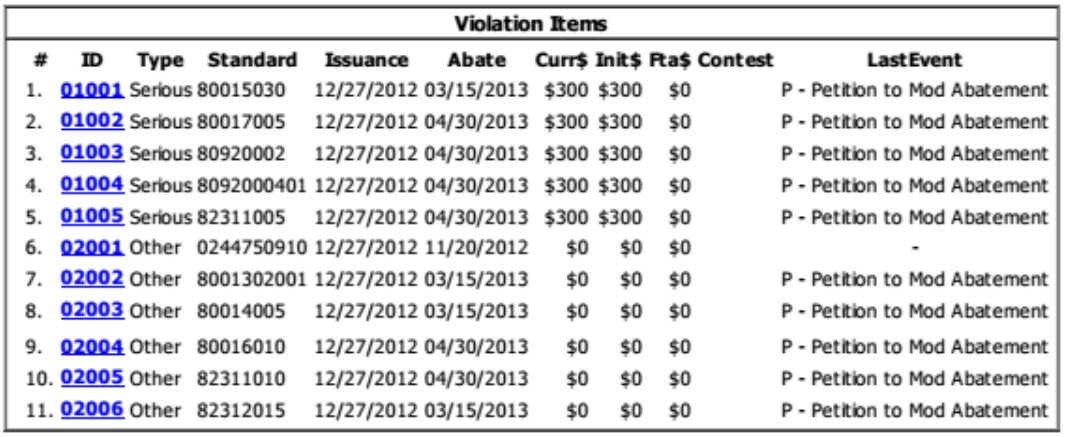


Figure 2: Histogram of vote-shares across focal NLRB elections with at least 20 votes cast

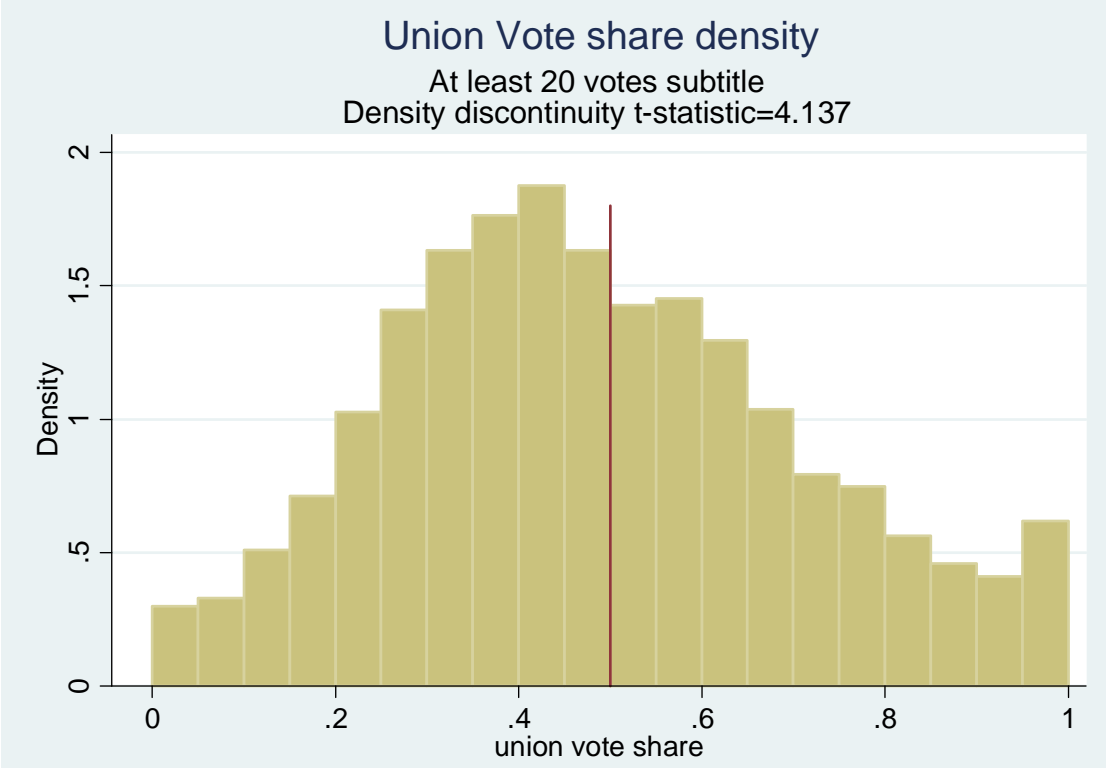


Figure 3: Average annual establishment (a) inspection rate, (b) labor-representative share, (c) violation index, (d) penalty index, and (e) injury index by vote-share bin in pre- and postelection periods

(a) Inspection rate

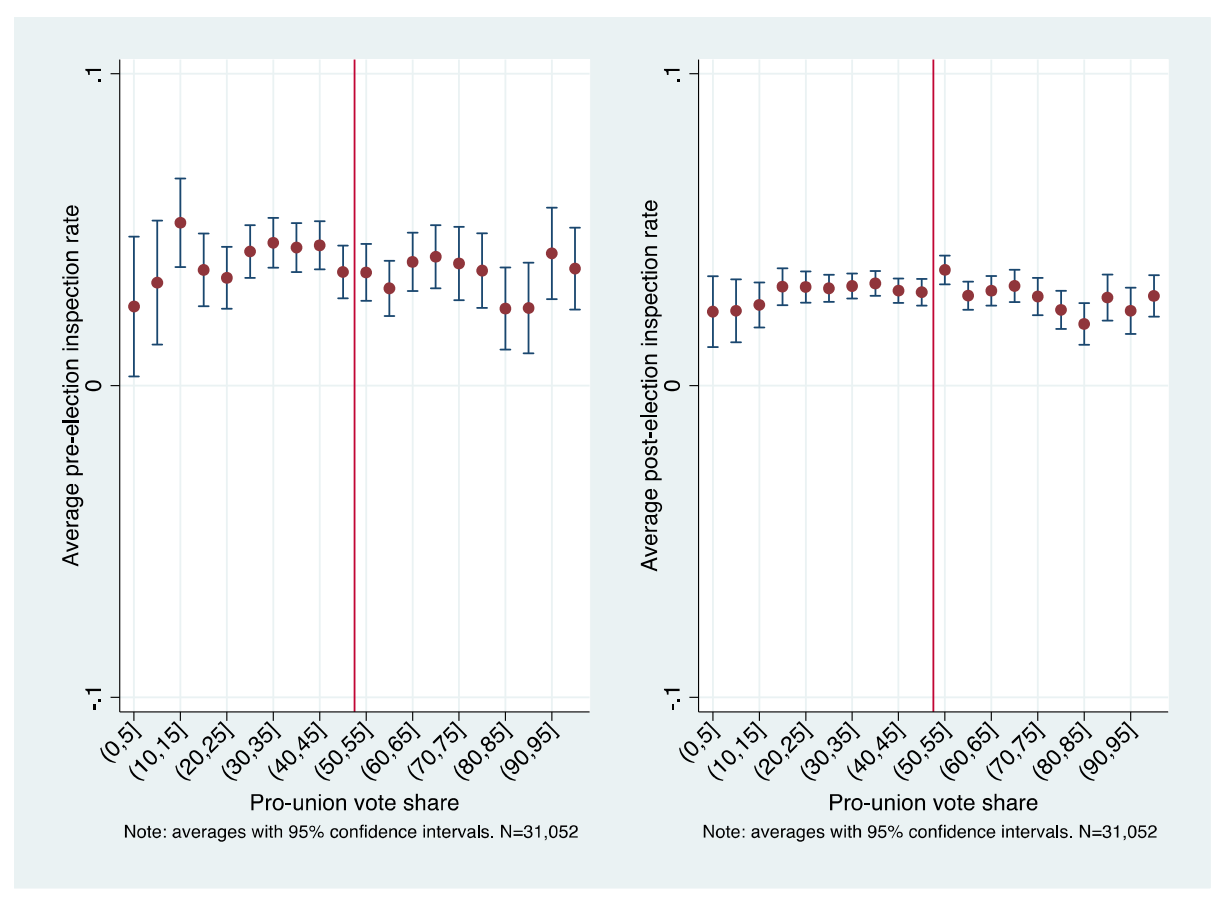

(b) Labor-representative share

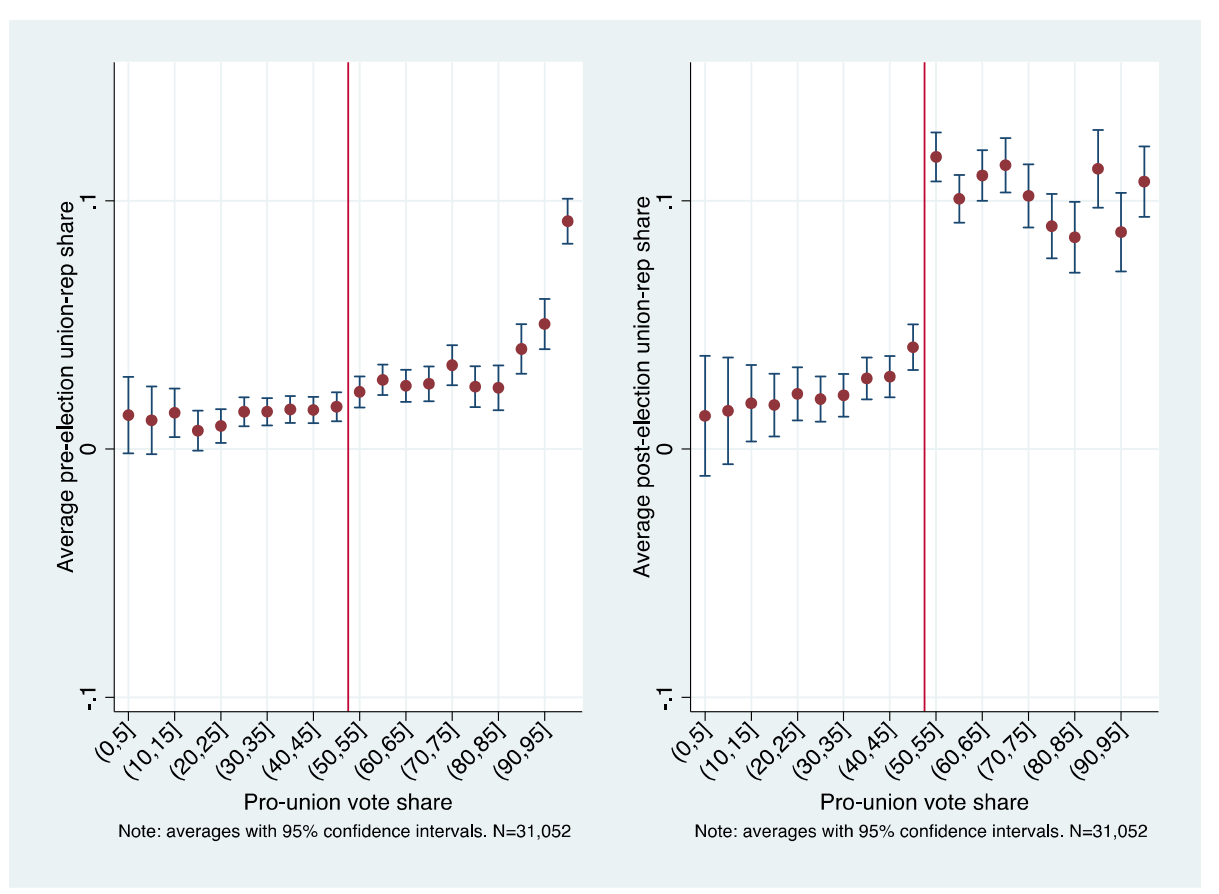


(c) Violation index
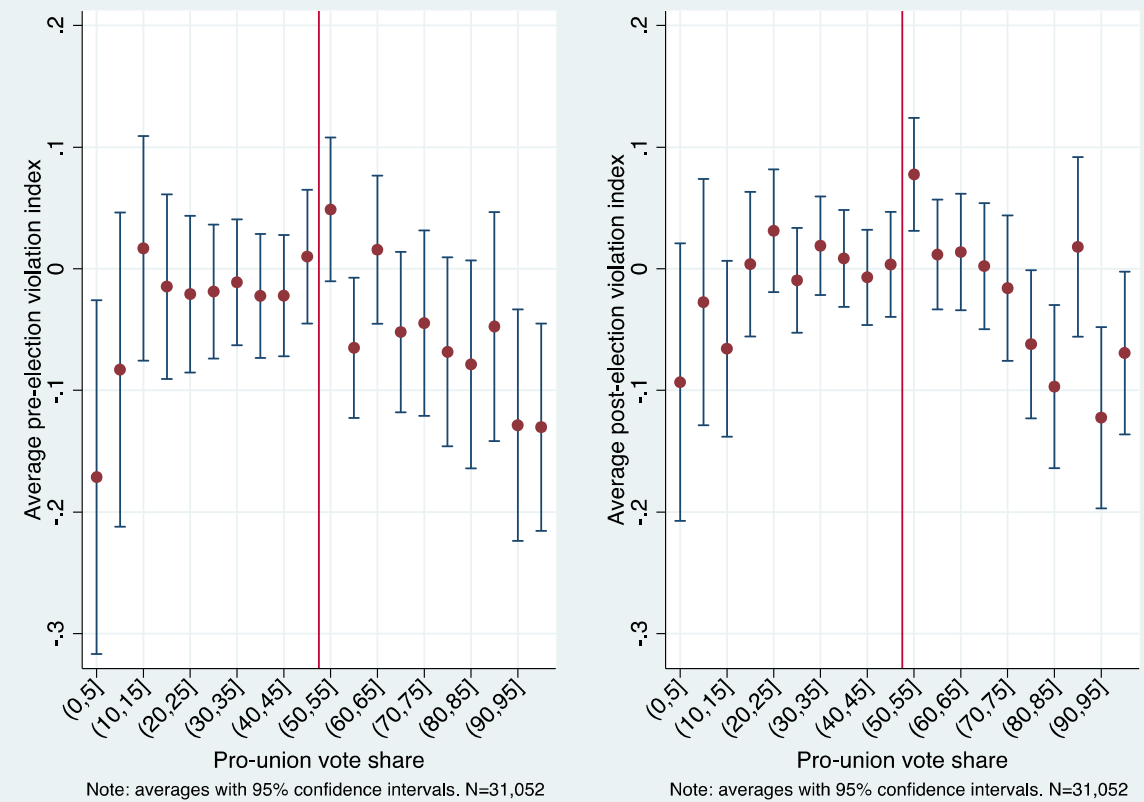

(d) Penalty index
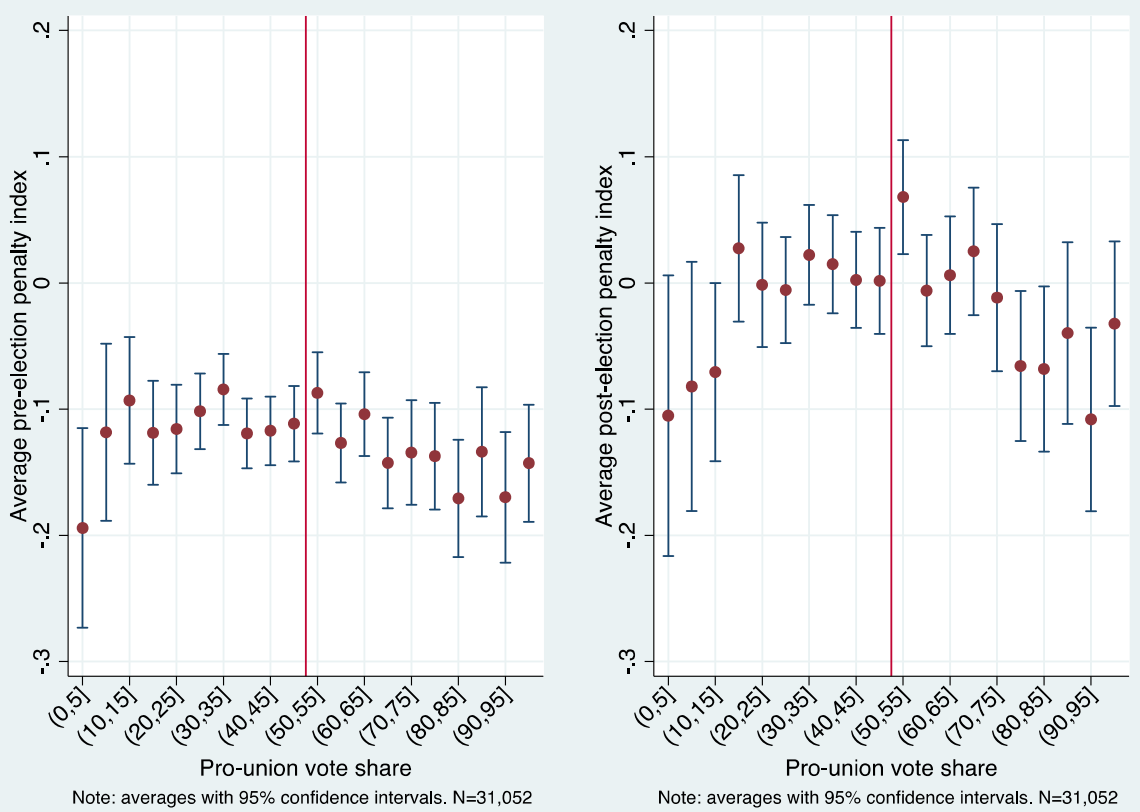
(e) Injury index
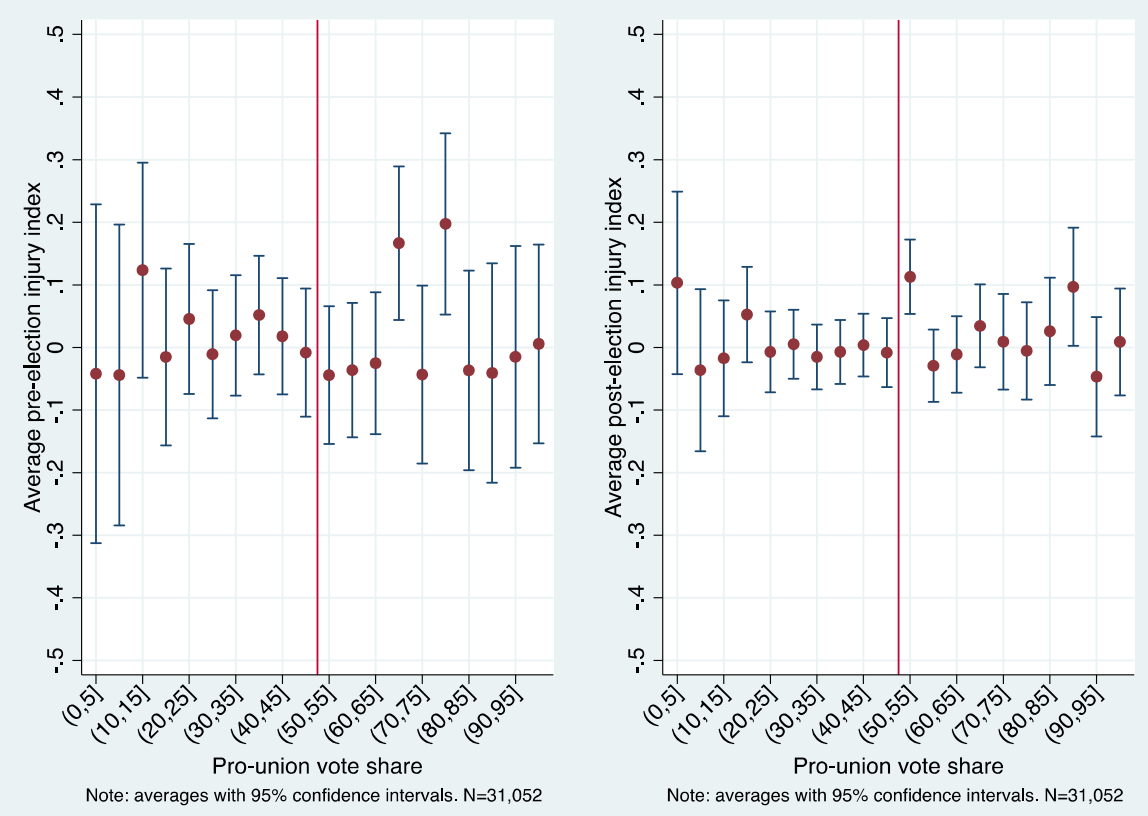
Figure 4: Estimated effects on (a) inspection rate, (b) labor-representative share, (c) violation index, (d) penalty index, and (e) injury index by bargaining-unit-size tercile

(a) Inspection rate

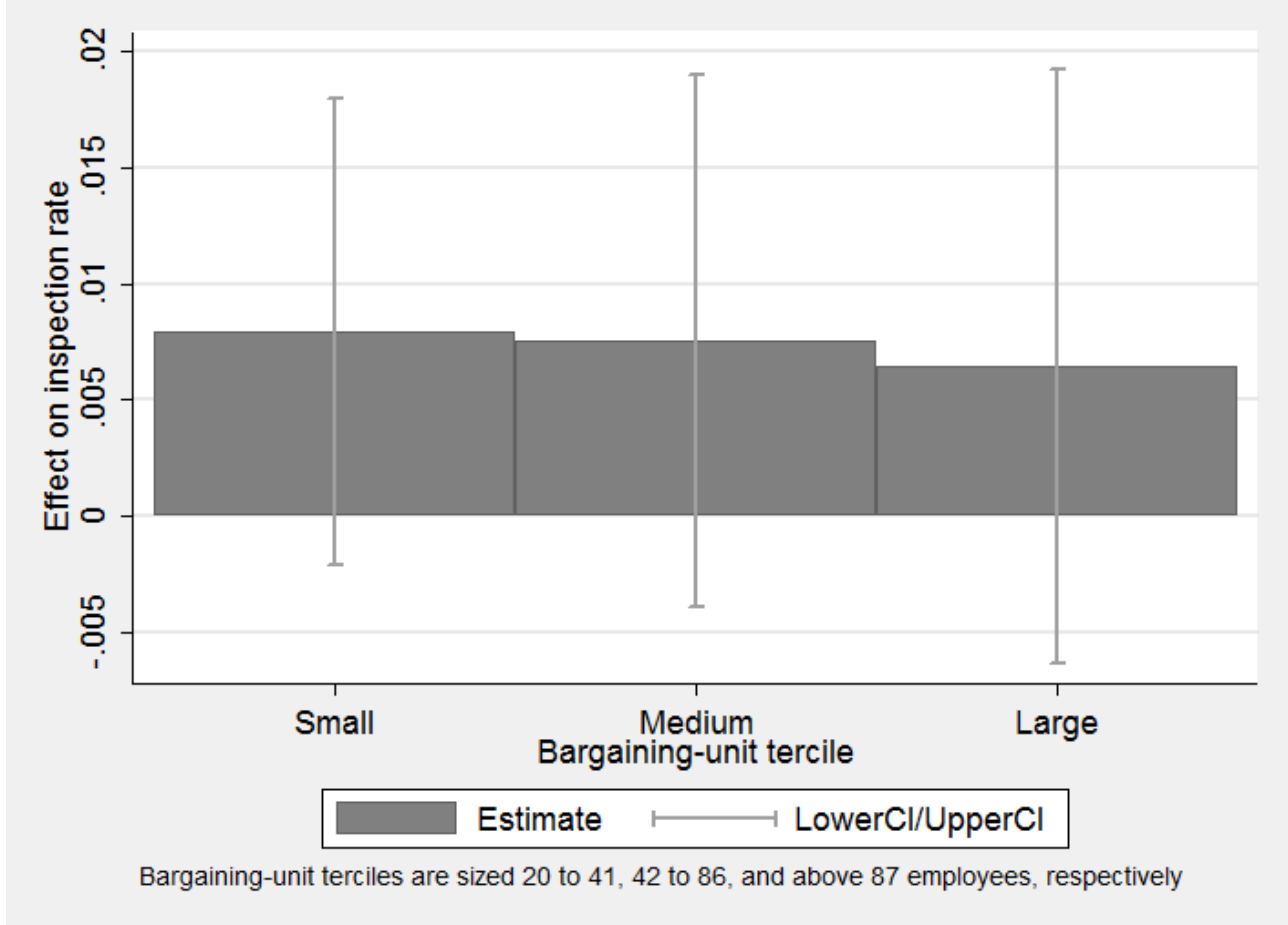

(b) Labor-representative share

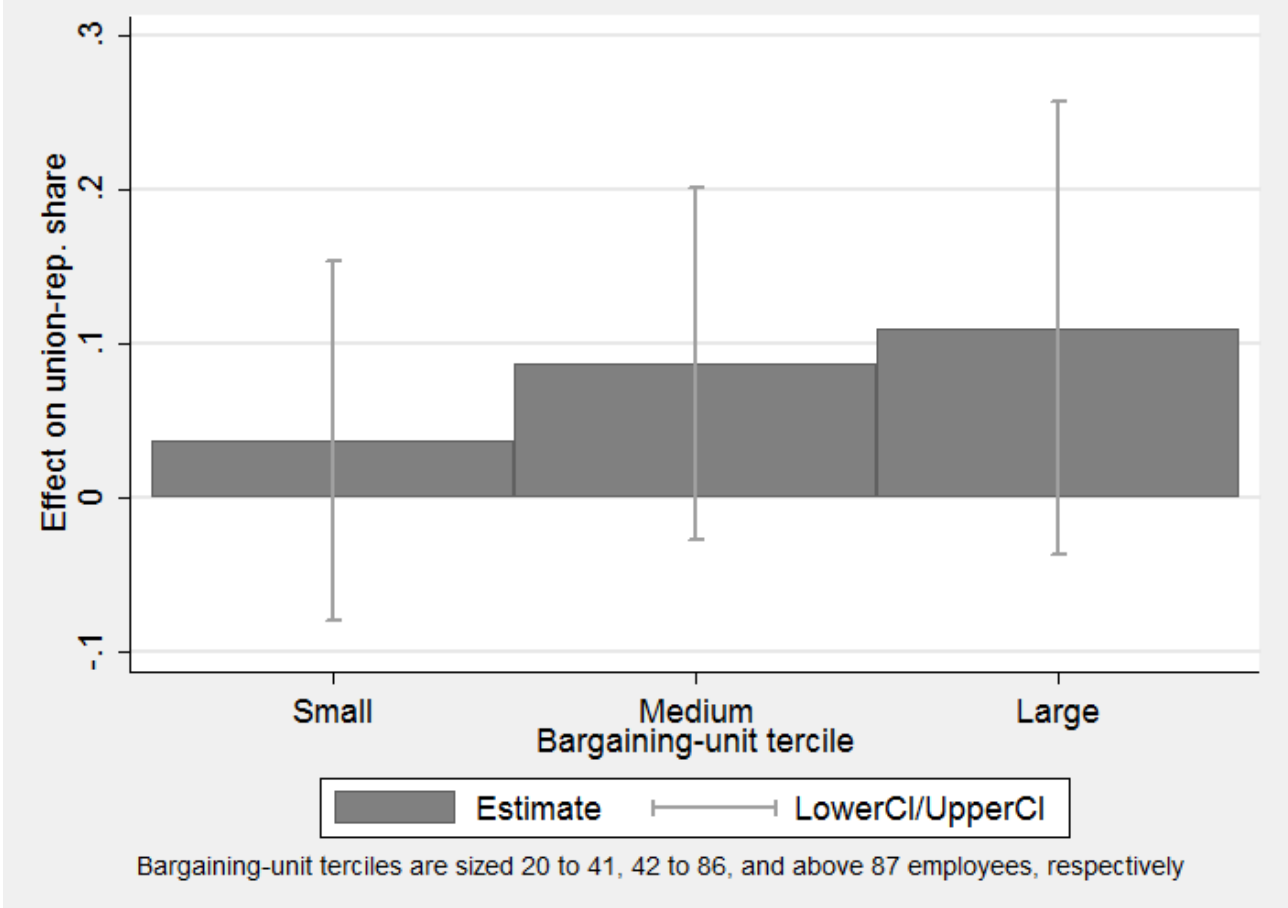


(c) Violation index

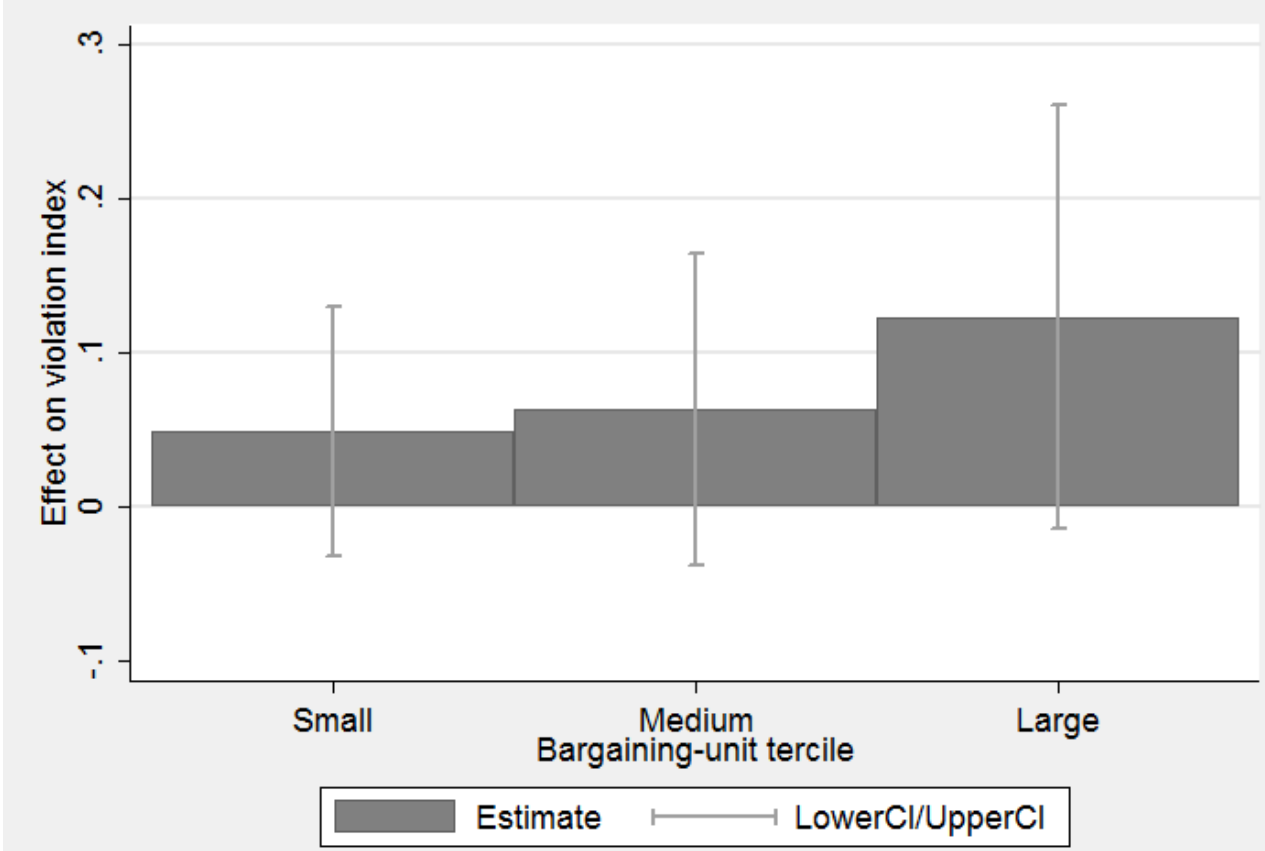

Bargaining-unit terciles are sized 20 to 41,42 to 86 , and above 87 employees, respectively

(d) Penalty index

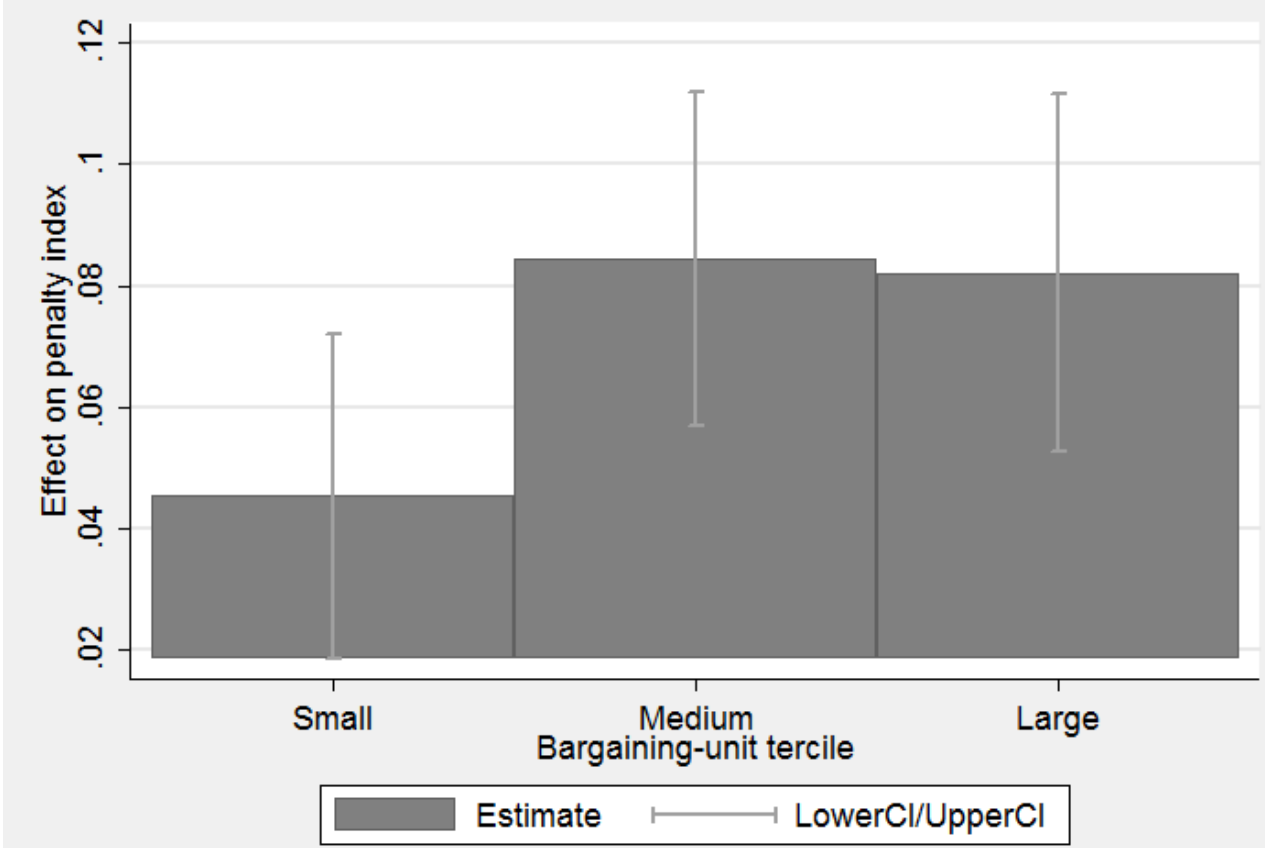

Bargaining-unit terciles are sized 20 to 41,42 to 86 , and above 87 employees, respectively 
(e) Injury index

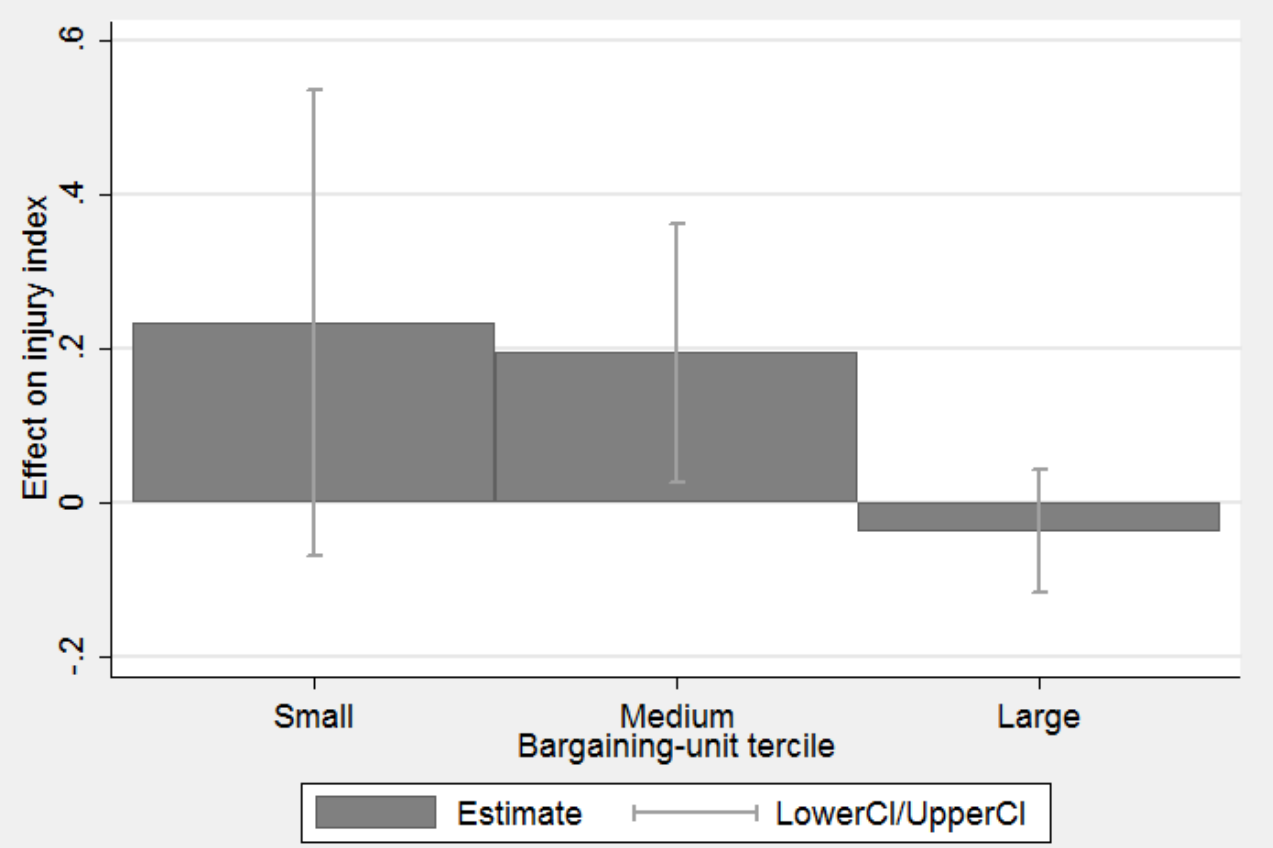

Bargaining-unit terciles are sized 20 to 41,42 to 86 , and above 87 employees, respectively 


\section{Appendix A: Additional Detail on Variable Construction}

To construct the merged NLRB election and OSHA inspection panel, we use a series of data cleaning and matching steps aimed at creating reliable linkages to records on the same establishment across time and source.

1. Preprocess each record to create standardized format:

a. standardize state names to postal abbreviations,

b. all street/avenues/road... abbreviations to st/ave/rd

c. establishment names in a uniform case and standardize abbreviations (corp/corporation/co to corp, inc/incorporated/Inc to inc...)

2. Crosswalk later NLRB election industry codes back to SIC87.

a. NLRB switched from SIC-1978 to SIC-1987 to NAICS-2002 industry codes. In each The SIC-78 to SIC-87 has negligible impact on the first and second digits of the industry code, which is all we use. The switch to NAICS-02 is more consequential. . OSHA never switched to NAICS so we convert NLRB industry codes that appear to be NAICS-02 back to SIC-87. Here's how.

b. We judge whether each NLRB election's industry is coded under SIC or NAICS by merging its 2-digit industry code to both the SIC industry and the NAICS industry with that number.

i. In some cases, the 2-digit number matches to only an SIC code and not a NAICS code. That is SIC.

ii. In other cases, the 2-digit number matches to only a NAICS code and not an SIC code. That is NAICS.

iii. In the rest of the cases, the 2-digit number matches to both an SIC code and a NAICS code. We inspect these by hand sorting by election date and paying attention to establishment name. We know that earlier elections are generally SIC coded as NAICS did not exist in early years of the study, although there appears to be some back-coding of pre2002 elections under NAICS. Within each 2-digit industry code, there is usually a year where establishment names switch from being that of the SIC code to that of the NAICS code. We use that break point to assign each NLRB election's industry code as either SIC or NAICS.

c. For election with NAICS codes, we use the NAICS-02 to SIC-87 crosswalk provided by the Bureau of Labor Statistics under its Current Employment Statistics (CES) program. ${ }^{26}$

i. For many NAICS codes, the mapping to SIC is one-to-one. We convert these directly.

ii. For the other NAICS codes, the mapping is to multiple SIC codes and the crosswalk provides probabilities based on employment shares. In those cases $(5,579)$, we create multiple versions of the NLRB election record, each associated with a different SIC code and share.

3. Create longitudinal links within the NLRB election data to identify multiple elections in the same establishment over time.

\footnotetext{
${ }^{26} \mathrm{http}: / /$ www.bls.gov/ces/naicstosic2.htm
} 
a. Split the NLRB data into subsamples with the same state-SIC2 combination.

b. Within subsample, use Stata command strgroup to find multiple NLRB election records with the same establishment name, street address (where available), and city. This generates a set of potential links with various match qualities. We inspect by hand to judge the best match-quality threshold (0.25). We also present results using alternative thresholds (0.2 and 0.3).

4. Create links between NLRB records and OSHA records to identify the same establishment in both data sets.

a. For each OSHA record, search within the NLRB records with the same stateSIC2 combination using the Stata command reclink to find NLRB elections that occurred in establishments with the same name, street address (where available), and city. We inspect by hand to judge the best match-quality threshold ( 0.8853 for matches to NLRB records with street address and 0.8895 for matches to NLRB records without address).

5. In cases where the NLRB election has only one associated SIC code, this process creates a longitudinal establishment identifier across datasets.

6. In cases where the NLRB election has multiple associated SICS codes from the NAICS crosswalk process, further refinement is needed. Here, each election has multiple possible SIC codes. We choose one using information from OSHA records and from the CES cross-walk's employment shares.

a. Where available, use information from the OSHA code to classify the establishment into the correct SIC industry.

i. Calculate the number of OSHA records connected to each election-SIC pair for that election.

ii. Keep the election-SIC record(s) with the highest number of linked OSHA records. Drop the records of the other possible election-SIC pairs for that election.

b. Use information from CES employment shares to classify the establishment into the correct SIC industry.

i. If multiple possible SIC matched to the same, highest number of OSHA records for an election $(4,418)$, then use CES employment share to break the tie. Keep the election-SIC record with the highest employment share. Drop the records of the other possible election-SIC pairs for that election.

ii. If an election had no OSHA matches for any of its possible SICs, then keep the record with the SIC code that has with the highest employment share from the CES crosswalk $(11,182)$. Drop the records of the other possible election-SIC pairs for that election.

c. For a few elections (89), there is still a tie between two possible SIC codes that have the same highest-number of linked OSHA records and the same employment shares. In those cases, we pick one of its possible SIC codes at random to keep and drop the other(s).

This process produces a set of measured unique establishments each with linked NLRB election record(s), perhaps linked OSHA records, and a single SIC code. 


\section{Appendix B: Additional Tables \& Figures}

Table 8: Distribution of elections across industry divisions

\begin{tabular}{clrr}
\hline Div. & Industry & Freq. & Percent \\
\hline B & Mining & 280 & 0.90 \\
C & Construction & 1,627 & 5.24 \\
D & Manufacturing & 10,878 & 35.03 \\
E & Transportation, Communications, Electric, Gas, And Sanitary & 5,456 & 17.57 \\
F & Wholesale Trade & 1,683 & 5.42 \\
G & Retail Trade & 2,067 & 6.66 \\
H & Finance, Insurance, And Real Estate & 245 & 0.79 \\
I & Services & 8,816 & 28.39 \\
\hline Total & & 31,052 & 100 \\
\hline
\end{tabular}


Table 9: Effect of union certification on post-election inspection rate at IK-optimal bandwidth 0.128 with varying sets of conditioning variables

\begin{tabular}{|c|c|c|c|c|}
\hline $\begin{array}{l}\text { Specification: } \\
\text { Predictors } \\
\end{array}$ & (1) & (2) & (3) & (4) \\
\hline Union certified & $\begin{array}{l}0.00825^{* *} \\
(0.00370)\end{array}$ & $\begin{array}{l}0.00860 * * \\
(0.00360)\end{array}$ & $\begin{array}{l}0.00693 * * \\
(0.00348)\end{array}$ & $\begin{array}{l}0.00738 * * \\
(0.00347)\end{array}$ \\
\hline Vote share & $\begin{array}{l}-0.0286 \\
(0.0286)\end{array}$ & $\begin{array}{l}-0.0201 \\
(0.0278)\end{array}$ & $\begin{array}{l}-0.0184 \\
(0.0269)\end{array}$ & $\begin{array}{l}-0.0162 \\
(0.0268)\end{array}$ \\
\hline Vote share*certified & $\begin{array}{l}-0.0392 \\
(0.0433)\end{array}$ & $\begin{array}{l}-0.0514 \\
(0.0421)\end{array}$ & $\begin{array}{l}-0.0398 \\
(0.0407)\end{array}$ & $\begin{array}{l}-0.0376 \\
(0.0405)\end{array}$ \\
\hline Pre-election violation index & & & $\begin{array}{l}-0.00589 * * * \\
(0.000926)\end{array}$ & $\begin{array}{l}-0.00579 * * * \\
(0.000921)\end{array}$ \\
\hline Pre-election penalty index & & & $\begin{array}{l}0.0363 * * * \\
(0.00192)\end{array}$ & $\begin{array}{l}0.0347 * * * \\
(0.00191)\end{array}$ \\
\hline $\begin{array}{l}\text { Pre-election labor- } \\
\text { representative share }\end{array}$ & & & $\begin{array}{l}0.0641 * * * \\
(0.00626)\end{array}$ & $\begin{array}{l}0.0654 * * * \\
(0.00623)\end{array}$ \\
\hline Pre-election inspection rate & & $\begin{array}{l}0.113 * * * \\
(0.00391)\end{array}$ & $\begin{array}{l}0.0678 * * * \\
(0.00443)\end{array}$ & $\begin{array}{l}0.0639 * * * \\
(0.00443)\end{array}$ \\
\hline Pre-election injury index & & & $\begin{array}{l}-0.000764^{* *} \\
(0.000373)\end{array}$ & $\begin{array}{l}-0.000690^{*} \\
(0.000371)\end{array}$ \\
\hline Eligible voters & & & $\begin{array}{l}5.55 \mathrm{e}-05^{* * *} \\
(5.53 \mathrm{e}-06)\end{array}$ & $\begin{array}{l}5.09 \mathrm{e}-05^{* * *} \\
(5.53 \mathrm{e}-06)\end{array}$ \\
\hline Eligible voters squared & & & $\begin{array}{l}-5.45 \mathrm{e}-09^{* * *} \\
(9.68 \mathrm{e}-10)\end{array}$ & $\begin{array}{l}-5.06 \mathrm{e}-09^{* * * *} \\
(9.64 \mathrm{e}-10)\end{array}$ \\
\hline Industry Div. C & & & & $\begin{array}{l}0.00796 \\
(0.00945)\end{array}$ \\
\hline Industry Div. D & & & & $\begin{array}{l}0.0344 * * * \\
(0.00917)\end{array}$ \\
\hline Industry Div. E & & & & $\begin{array}{l}0.0109 \\
(0.00874)\end{array}$ \\
\hline Industry Div. F & & & & $\begin{array}{l}0.0148 \\
(0.00976)\end{array}$ \\
\hline Industry Div. G & & & & $\begin{array}{l}0.00565 \\
(0.00969)\end{array}$ \\
\hline Industry Div. $\mathrm{H}$ & & & & $\begin{array}{l}0.00225 \\
(0.0137)\end{array}$ \\
\hline Industry Div. I & & & & $\begin{array}{l}0.0193 * * \\
(0.00934)\end{array}$ \\
\hline $\begin{array}{l}\text { Average fatality rate in 2- } \\
\text { digit SIC code }\end{array}$ & & & & $\begin{array}{l}0.000284 * * \\
(0.000137)\end{array}$ \\
\hline Constant & $\begin{array}{l}0.0289 * * * \\
(0.00250)\end{array}$ & $\begin{array}{l}0.0248 * * * \\
(0.00243)\end{array}$ & $\begin{array}{l}0.0236 * * * \\
(0.00244)\end{array}$ & $\begin{array}{l}1.17 \mathrm{e}-05 \\
(0.00962)\end{array}$ \\
\hline Adj. R-squared & 0.000195 & 0.0566 & 0.115 & 0.124 \\
\hline
\end{tabular}

Note: Estimate (SE). ${ }^{* *}$ Significant at the $1 \%$ level, ${ }^{* *}$ Significant at the $5 \%$ level, ${ }^{*}$ Significant at the $10 \%$ level. $\mathrm{N}=13,830$. 
Table 10: Effect of union certification on post-election union-rep share at IK-optimal bandwidth 0.151 with varying sets of conditioning variables

\begin{tabular}{|c|c|c|c|c|}
\hline $\begin{array}{l}\text { Specification: } \\
\text { Predictors }\end{array}$ & (1) & (2) & (3) & (4) \\
\hline Union certified & $\begin{array}{l}0.0732 * * * \\
(0.00854)\end{array}$ & $\begin{array}{l}0.0711 * * * \\
(0.00840)\end{array}$ & $\begin{array}{l}0.0705 * * * \\
(0.00835)\end{array}$ & $\begin{array}{l}0.0713 * * * \\
(0.00832)\end{array}$ \\
\hline Vote share & $\begin{array}{l}0.122^{*} \\
(0.0660)\end{array}$ & $\begin{array}{l}0.119^{*} \\
(0.0649)\end{array}$ & $\begin{array}{l}0.139^{* *} \\
(0.0645)\end{array}$ & $\begin{array}{l}0.138^{* *} \\
(0.0643)\end{array}$ \\
\hline Vote share*certified & $\begin{array}{l}-0.200 * * \\
(0.0999)\end{array}$ & $\begin{array}{l}-0.205^{* *} \\
(0.0982)\end{array}$ & $\begin{array}{l}-0.207 * * \\
(0.0975)\end{array}$ & $\begin{array}{l}-0.208 * * \\
(0.0972)\end{array}$ \\
\hline Pre-election violation index & & & $\begin{array}{l}0.000387 \\
(0.00222)\end{array}$ & $\begin{array}{l}0.000649 \\
(0.00221)\end{array}$ \\
\hline Pre-election penalty index & & & $\begin{array}{l}0.00966^{* *} \\
(0.00460)\end{array}$ & $\begin{array}{l}0.00664 \\
(0.00459)\end{array}$ \\
\hline $\begin{array}{l}\text { Pre-election union- } \\
\text { representative share }\end{array}$ & & $\begin{array}{l}0.316^{* * *} \\
(0.0144)\end{array}$ & $\begin{array}{l}0.265 * * * \\
(0.0150)\end{array}$ & $\begin{array}{l}0.265 * * * \\
(0.0149)\end{array}$ \\
\hline Pre-election inspection rate & & & $\begin{array}{l}0.0683^{* * *} \\
(0.0106)\end{array}$ & $\begin{array}{l}0.0630^{* * *} \\
(0.0106)\end{array}$ \\
\hline Pre-election injury index & & & $\begin{array}{l}0.00238^{* * *} \\
(0.000893)\end{array}$ & $\begin{array}{l}0.00245^{* * *} \\
(0.000890)\end{array}$ \\
\hline Eligible voters & & & $\begin{array}{l}0.000106^{* * *} \\
(1.32 \mathrm{e}-05)\end{array}$ & $\begin{array}{l}9.36 \mathrm{e}-05^{* * *} \\
(1.33 \mathrm{e}-05)\end{array}$ \\
\hline Eligible voters squared & & & $\begin{array}{l}-1.03 \mathrm{e}-08^{* * * *} \\
(2.32 \mathrm{e}-09)\end{array}$ & $\begin{array}{l}-9.12 \mathrm{e}-09^{* * * *} \\
(2.31 \mathrm{e}-09)\end{array}$ \\
\hline Industry Div. C & & & & $\begin{array}{l}0.00624 \\
(0.0227)\end{array}$ \\
\hline Industry Div. D & & & & $\begin{array}{l}0.0619 * * * \\
(0.0220)\end{array}$ \\
\hline Industry Div. E & & & & $\begin{array}{l}0.0286 \\
(0.0210)\end{array}$ \\
\hline Industry Div. F & & & & $\begin{array}{l}0.0216 \\
(0.0234)\end{array}$ \\
\hline Industry Div. G & & & & $\begin{array}{l}-0.00446 \\
(0.0232)\end{array}$ \\
\hline Industry Div. H & & & & $\begin{array}{l}-0.00900 \\
(0.0328)\end{array}$ \\
\hline Industry Div. I & & & & $\begin{array}{l}0.0425^{*} \\
(0.0224)\end{array}$ \\
\hline $\begin{array}{l}\text { Average fatality rate in 2- } \\
\text { digit SIC code }\end{array}$ & & & & $\begin{array}{l}-0.000277 \\
(0.000328)\end{array}$ \\
\hline Constant & $\begin{array}{l}0.0419 * * * \\
(0.00576)\end{array}$ & $\begin{array}{l}0.0365 * * * \\
(0.00567)\end{array}$ & $\begin{array}{l}0.0250^{* * *} \\
(0.00583)\end{array}$ & $\begin{array}{l}-0.0132 \\
(0.0231)\end{array}$ \\
\hline Adj. R-squared & 0.0261 & 0.0589 & 0.0711 & 0.0786 \\
\hline
\end{tabular}

Note: Estimate (SE). ${ }^{* * *}$ Significant at the $1 \%$ level, ${ }^{* *}$ Significant at the $5 \%$ level, ${ }^{*}$ Significant at the $10 \%$ level. $\mathrm{N}=13,830$ 
Table 11: Effect of union certification on post-election violation index at IK-optimal bandwidth 0.197 with varying sets of conditioning variables

\begin{tabular}{|c|c|c|c|c|}
\hline $\begin{array}{l}\text { Specification: } \\
\text { Predictors }\end{array}$ & (1) & (2) & (3) & (4) \\
\hline Union certified & $\begin{array}{l}0.0788 * * \\
(0.0345)\end{array}$ & $\begin{array}{l}0.0746^{* *} \\
(0.0339)\end{array}$ & $\begin{array}{l}0.0668 * * \\
(0.0336)\end{array}$ & $\begin{array}{l}0.0796^{* *} \\
(0.0332)\end{array}$ \\
\hline Vote share & $\begin{array}{l}-0.130 \\
(0.199)\end{array}$ & $\begin{array}{l}-0.146 \\
(0.196)\end{array}$ & $\begin{array}{l}-0.0603 \\
(0.194)\end{array}$ & $\begin{array}{l}-0.0132 \\
(0.192)\end{array}$ \\
\hline Vote share*certified & $\begin{array}{l}-0.329 \\
(0.307)\end{array}$ & $\begin{array}{l}-0.252 \\
(0.301)\end{array}$ & $\begin{array}{l}-0.296 \\
(0.299)\end{array}$ & $\begin{array}{l}-0.273 \\
(0.296)\end{array}$ \\
\hline Pre-election violation index & & $\begin{array}{l}0.139 * * * \\
(0.00543)\end{array}$ & $\begin{array}{l}0.0247 * * * \\
(0.00945)\end{array}$ & $\begin{array}{l}0.0248 * * * \\
(0.00935)\end{array}$ \\
\hline Pre-election penalty index & & & $\begin{array}{l}0.216^{* * * *} \\
(0.0185)\end{array}$ & $\begin{array}{l}0.190 * * * \\
(0.0184)\end{array}$ \\
\hline $\begin{array}{l}\text { Pre-election labor- } \\
\text { representative share }\end{array}$ & & & $\begin{array}{l}0.288 * * * \\
(0.0625)\end{array}$ & $\begin{array}{l}0.318^{* * *} \\
(0.0618)\end{array}$ \\
\hline Pre-election inspection rate & & & $\begin{array}{l}0.359 * * * \\
(0.0442)\end{array}$ & $\begin{array}{l}0.279 * * * \\
(0.0439)\end{array}$ \\
\hline Pre-election injury index & & & $\begin{array}{l}-0.0103 * * * \\
(0.00315)\end{array}$ & $\begin{array}{l}-0.00896^{* * * *} \\
(0.00311)\end{array}$ \\
\hline Eligible voters & & & $\begin{array}{l}0.000261 * * * \\
(5.55 \mathrm{e}-05)\end{array}$ & $\begin{array}{l}0.000189^{* * *} \\
(5.52 \mathrm{e}-05)\end{array}$ \\
\hline Eligible voters squared & & & $\begin{array}{l}-3.23 \mathrm{e}-08^{* * *} \\
(1.06 \mathrm{e}-08)\end{array}$ & $\begin{array}{l}-2.61 \mathrm{e}-08^{* *} \\
(1.05 \mathrm{e}-08)\end{array}$ \\
\hline Industry Div. $\mathrm{C}$ & & & & $\begin{array}{l}0.109 \\
(0.0946)\end{array}$ \\
\hline Industry Div. D & & & & $\begin{array}{l}0.542 * * * \\
(0.0921)\end{array}$ \\
\hline Industry Div. E & & & & $\begin{array}{l}0.113 \\
(0.0878)\end{array}$ \\
\hline Industry Div. F & & & & $\begin{array}{l}0.254 * * * \\
(0.0976)\end{array}$ \\
\hline Industry Div. G & & & & $\begin{array}{l}0.175^{*} \\
(0.0970)\end{array}$ \\
\hline Industry Div. H & & & & $\begin{array}{l}0.154 \\
(0.135)\end{array}$ \\
\hline Industry Div. I & & & & $\begin{array}{l}0.222 * * \\
(0.0937)\end{array}$ \\
\hline $\begin{array}{l}\text { Average fatality rate in } 2- \\
\text { digit SIC code }\end{array}$ & & & & $\begin{array}{l}0.00561 * * * \\
(0.00136)\end{array}$ \\
\hline Constant & $\begin{array}{l}-0.00742 \\
(0.0230)\end{array}$ & $\begin{array}{l}-0.00736 \\
(0.0226)\end{array}$ & $\begin{array}{l}-0.0261 \\
(0.0234)\end{array}$ & $\begin{array}{l}-0.382 * * * \\
(0.0962)\end{array}$ \\
\hline
\end{tabular}

\begin{tabular}{lcccc} 
Adj. R-squared & 0.000165 & 0.0352 & 0.0516 & 0.0733 \\
\hline Note: Estimate (SE). ***Significant at the $1 \%$ level, ${ }^{* *}$ Significant at the $5 \%$ level, ${ }^{*}$ Significant at the
\end{tabular} $10 \%$ level. $\mathrm{N}=18,053$. 
Table 12: Effect of union certification on post-election penalty index at IK-optimal bandwidth 0.153 with varying sets of conditioning variables

\begin{tabular}{|c|c|c|c|c|}
\hline $\begin{array}{l}\text { Specification: } \\
\text { Predictors }\end{array}$ & (1) & (2) & (3) & (4) \\
\hline Union certified & $\begin{array}{l}0.0731^{*} \\
(0.0397)\end{array}$ & $\begin{array}{l}0.0681^{*} \\
(0.0388)\end{array}$ & $\begin{array}{l}0.0657^{*} \\
(0.0386)\end{array}$ & $\begin{array}{l}0.0754 * * \\
(0.0381)\end{array}$ \\
\hline Vote share & $\begin{array}{l}-0.137 \\
(0.307)\end{array}$ & $\begin{array}{l}-0.159 \\
(0.300)\end{array}$ & $\begin{array}{l}-0.102 \\
(0.298)\end{array}$ & $\begin{array}{l}-0.0591 \\
(0.295)\end{array}$ \\
\hline Vote share*certified & $\begin{array}{l}-0.492 \\
(0.464)\end{array}$ & $\begin{array}{l}-0.417 \\
(0.453)\end{array}$ & $\begin{array}{l}-0.454 \\
(0.451)\end{array}$ & $\begin{array}{l}-0.375 \\
(0.446)\end{array}$ \\
\hline Pre-election violation index & & & $\begin{array}{l}0.0286^{* * * *} \\
(0.0103)\end{array}$ & $\begin{array}{l}0.0300 * * * \\
(0.0101)\end{array}$ \\
\hline Pre-election penalty index & & $\begin{array}{l}0.297 * * * \\
(0.0117)\end{array}$ & $\begin{array}{l}0.187 * * * \\
(0.0213)\end{array}$ & $\begin{array}{l}0.160 * * * \\
(0.0210)\end{array}$ \\
\hline $\begin{array}{l}\text { Pre-election labor- } \\
\text { representative share }\end{array}$ & & & $\begin{array}{l}0.290 * * * \\
(0.0693)\end{array}$ & $\begin{array}{l}0.320 * * * \\
(0.0685)\end{array}$ \\
\hline Pre-election inspection rate & & & $\begin{array}{l}0.434 * * * \\
(0.0491)\end{array}$ & $\begin{array}{l}0.364 * * * \\
(0.0487)\end{array}$ \\
\hline Pre-election injury index & & & $\begin{array}{l}-0.0167 * * * \\
(0.00413)\end{array}$ & $\begin{array}{l}-0.0153 * * * \\
(0.00408)\end{array}$ \\
\hline Eligible voters & & & $\begin{array}{l}0.000295 * * * \\
(6.12 \mathrm{e}-05)\end{array}$ & $\begin{array}{l}0.000222 * * * \\
(6.08 \mathrm{e}-05)\end{array}$ \\
\hline Eligible voters squared & & & $\begin{array}{l}-2.89 \mathrm{e}-08 * * * \\
(1.07 \mathrm{e}-08)\end{array}$ & $\begin{array}{l}-2.30 \mathrm{e}-08^{* *} \\
(1.06 \mathrm{e}-08)\end{array}$ \\
\hline Industry Div. C & & & & $\begin{array}{l}0.122 \\
(0.104)\end{array}$ \\
\hline Industry Div. D & & & & $\begin{array}{l}0.510 * * * \\
(0.101)\end{array}$ \\
\hline Industry Div. E & & & & $\begin{array}{l}0.107 \\
(0.0961)\end{array}$ \\
\hline Industry Div. F & & & & $\begin{array}{l}0.240 * * \\
(0.107)\end{array}$ \\
\hline Industry Div. G & & & & $\begin{array}{l}0.126 \\
(0.107)\end{array}$ \\
\hline Industry Div. H & & & & $\begin{array}{l}0.0730 \\
(0.150)\end{array}$ \\
\hline Industry Div. I & & & & $\begin{array}{l}0.190^{*} \\
(0.103)\end{array}$ \\
\hline $\begin{array}{l}\text { Average fatality rate in } 2- \\
\text { digit SIC code }\end{array}$ & & & & $\begin{array}{l}0.00279^{*} \\
(0.00150)\end{array}$ \\
\hline Constant & $\begin{array}{l}-0.00411 \\
(0.0267)\end{array}$ & $\begin{array}{l}0.0286 \\
(0.0262)\end{array}$ & $\begin{array}{l}-0.0354 \\
(0.0270)\end{array}$ & $\begin{array}{l}-0.345^{* * *} \\
(0.106)\end{array}$ \\
\hline Adj. R-squared & $8.71 \mathrm{e}-05$ & 0.0444 & 0.0544 & 0.0771 \\
\hline
\end{tabular}

Note: Estimate (SE). ${ }^{* *}$ Significant at the $1 \%$ level, ${ }^{* *}$ Significant at the $5 \%$ level, ${ }^{*}$ Significant at the $10 \%$ level. $\mathrm{N}=13,830$. 
Table 13: Effect of union certification on post-election injury index at IK-optimal bandwidth 0.146 with varying sets of conditioning variables

\begin{tabular}{|c|c|c|c|c|}
\hline $\begin{array}{l}\text { Specification: } \\
\text { Predictors }\end{array}$ & (1) & (2) & (3) & (4) \\
\hline Union certified & $\begin{array}{l}0.121 * * \\
(0.0572)\end{array}$ & $\begin{array}{l}0.122 * * \\
(0.0570)\end{array}$ & $\begin{array}{l}0.117 * * \\
(0.0568)\end{array}$ & $\begin{array}{l}0.120^{* *} \\
(0.0568)\end{array}$ \\
\hline Vote share & $\begin{array}{l}-0.00500 \\
(0.442)\end{array}$ & $\begin{array}{l}0.0329 \\
(0.441)\end{array}$ & $\begin{array}{l}0.00305 \\
(0.439)\end{array}$ & $\begin{array}{l}0.0269 \\
(0.440)\end{array}$ \\
\hline Vote share*certified & $\begin{array}{l}-1.252^{*} \\
(0.669)\end{array}$ & $\begin{array}{l}-1.301^{*} \\
(0.666)\end{array}$ & $\begin{array}{l}-1.315^{* *} \\
(0.664)\end{array}$ & $\begin{array}{l}-1.324 * * \\
(0.664)\end{array}$ \\
\hline $\begin{array}{l}\text { Pre-election violation } \\
\text { index }\end{array}$ & & & $\begin{array}{l}-0.0329 * * \\
(0.0151)\end{array}$ & $\begin{array}{l}-0.0329 * * \\
(0.0151)\end{array}$ \\
\hline Pre-election penalty index & & & $\begin{array}{l}0.0791 * * \\
(0.0313)\end{array}$ & $\begin{array}{l}0.0767 * * \\
(0.0314)\end{array}$ \\
\hline $\begin{array}{l}\text { Pre-election labor- } \\
\text { representative share }\end{array}$ & & & $\begin{array}{l}0.895 * * * \\
(0.102)\end{array}$ & $\begin{array}{l}0.900 * * * \\
(0.102)\end{array}$ \\
\hline Pre-election inspection rate & & & $\begin{array}{l}-0.0282 \\
(0.0723)\end{array}$ & $\begin{array}{l}-0.0316 \\
(0.0726)\end{array}$ \\
\hline Pre-election injury index & & $\begin{array}{l}0.0628 * * * \\
(0.00578)\end{array}$ & $\begin{array}{l}0.0586^{* * *} \\
(0.00608)\end{array}$ & $\begin{array}{l}0.0585^{* * * *} \\
(0.00608)\end{array}$ \\
\hline Eligible voters & & & $\begin{array}{l}-0.000154^{*} \\
(9.01 \mathrm{e}-05)\end{array}$ & $\begin{array}{l}-0.000159^{*} \\
(9.06 \mathrm{e}-05)\end{array}$ \\
\hline Eligible voters squared & & & $\begin{array}{l}1.47 \mathrm{e}-08 \\
(1.58 \mathrm{e}-08)\end{array}$ & $\begin{array}{l}1.48 \mathrm{e}-08 \\
(1.58 \mathrm{e}-08)\end{array}$ \\
\hline Industry Div. C & & & & $\begin{array}{l}-0.0307 \\
(0.155)\end{array}$ \\
\hline Industry Div. D & & & & $\begin{array}{l}0.0104 \\
(0.150)\end{array}$ \\
\hline Industry Div. E & & & & $\begin{array}{l}0.0805 \\
(0.143)\end{array}$ \\
\hline Industry Div. F & & & & $\begin{array}{l}-0.0124 \\
(0.160)\end{array}$ \\
\hline Industry Div. G & & & & $\begin{array}{l}-0.0584 \\
(0.159)\end{array}$ \\
\hline Industry Div. $\mathrm{H}$ & & & & $\begin{array}{l}-0.0878 \\
(0.224)\end{array}$ \\
\hline Industry Div. I & & & & $\begin{array}{l}-0.0702 \\
(0.153)\end{array}$ \\
\hline $\begin{array}{l}\text { Average fatality rate in 2- } \\
\text { digit SIC code }\end{array}$ & & & & $\begin{array}{l}-0.00298 \\
(0.00224)\end{array}$ \\
\hline Constant & $\begin{array}{l}-0.00399 \\
(0.0386)\end{array}$ & $\begin{array}{l}-0.00243 \\
(0.0384)\end{array}$ & $\begin{array}{l}0.00828 \\
(0.0397)\end{array}$ & $\begin{array}{l}0.0378 \\
(0.158)\end{array}$ \\
\hline Adj. R-squared & 0.000312 & 0.00872 & 0.0153 & 0.0155 \\
\hline
\end{tabular}

Note: Estimate (SE). ***Significant at the $1 \%$ level, **Significant at the $5 \%$ level, *Significant at the $10 \%$ level. $\mathrm{N}=13,830$ 
Table 14: Number of Inspections by year in OSHA (1985-2014)

\begin{tabular}{|c|c|c|}
\hline Year & Inspection & Percent \\
\hline 1985 & 139,072 & 3.29 \\
\hline 1986 & 134,640 & 3.18 \\
\hline 1987 & 130,292 & 3.08 \\
\hline 1988 & 125,460 & 2.97 \\
\hline 1989 & 123,194 & 2.91 \\
\hline 1990 & 135,533 & 3.2 \\
\hline 1991 & 138,182 & 3.27 \\
\hline 1992 & 125,339 & 2.96 \\
\hline 1993 & 112,705 & 2.67 \\
\hline 1994 & 112,476 & 2.66 \\
\hline 1995 & 96,848 & 2.29 \\
\hline 1996 & 92,360 & 2.18 \\
\hline 1997 & 104,624 & 2.47 \\
\hline 1998 & 101,230 & 2.39 \\
\hline 1999 & 102,791 & 2.43 \\
\hline 2000 & 100,088 & 2.37 \\
\hline 2001 & 103,553 & 2.45 \\
\hline 2002 & 111,094 & 2.63 \\
\hline 2003 & 108,895 & 2.57 \\
\hline 2004 & 107,194 & 2.53 \\
\hline 2005 & 104,982 & 2.48 \\
\hline 2006 & 107,440 & 2.54 \\
\hline 2007 & 103,737 & 2.45 \\
\hline 2008 & 106,210 & 2.51 \\
\hline 2009 & 111,311 & 2.63 \\
\hline 2010 & 109,337 & 2.59 \\
\hline 2011 & 103,526 & 2.45 \\
\hline 2012 & 101,033 & 2.39 \\
\hline 2013 & 90,647 & 2.14 \\
\hline 2014 & 2,701 & 0.06 \\
\hline Total & $3,052,113$ & 72 \\
\hline
\end{tabular}


Figure 5: Number of fatal occupational injuries in OSHA database annually for 1970 to 2014

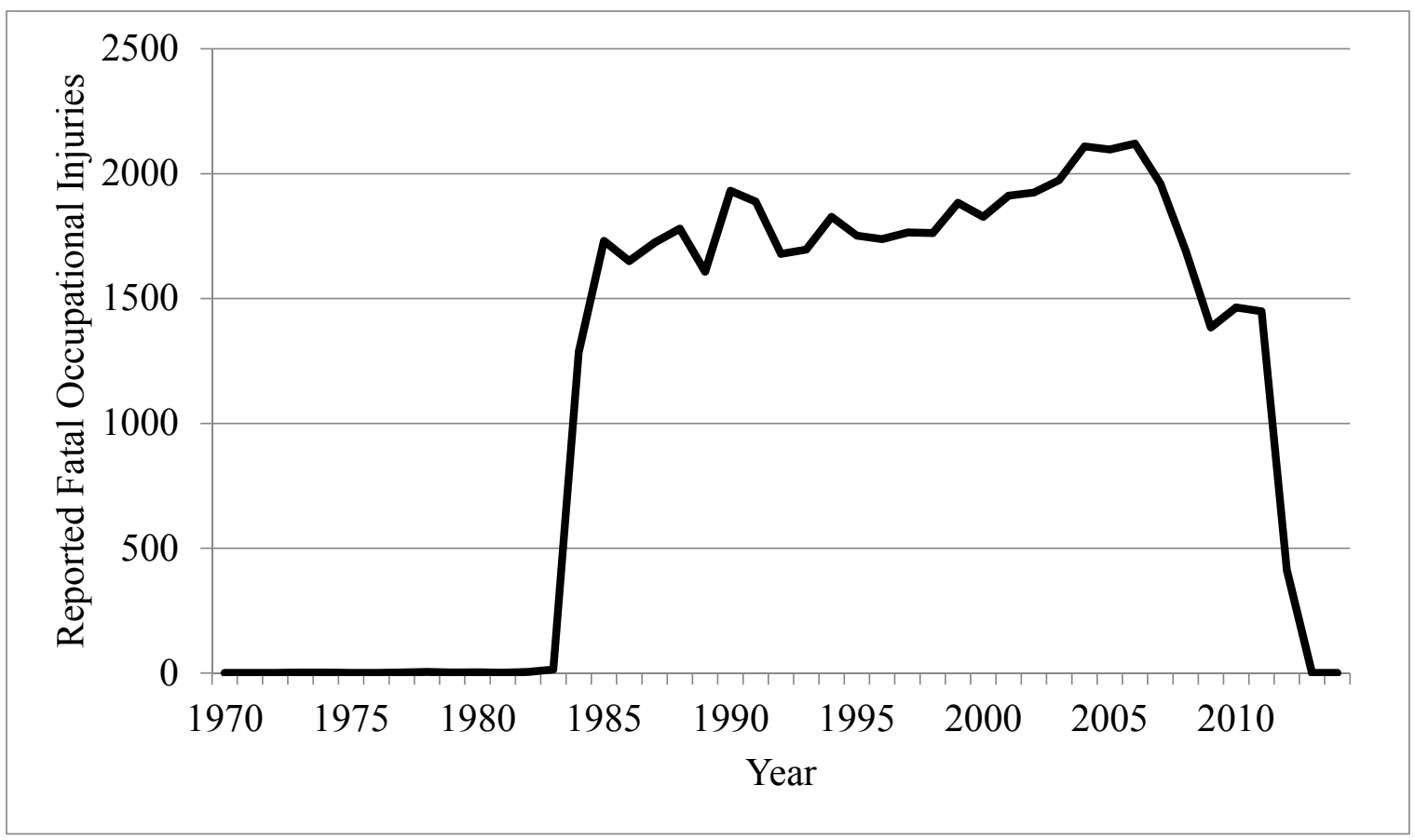


Figure 6: Comparison of trends in annual number of fatal injuries recorded in the Census of Fatal Occupational Injuries (CFOI) and the Occupational Safety and Health Administration enforcement database (OSHA) over 1992 to 2011

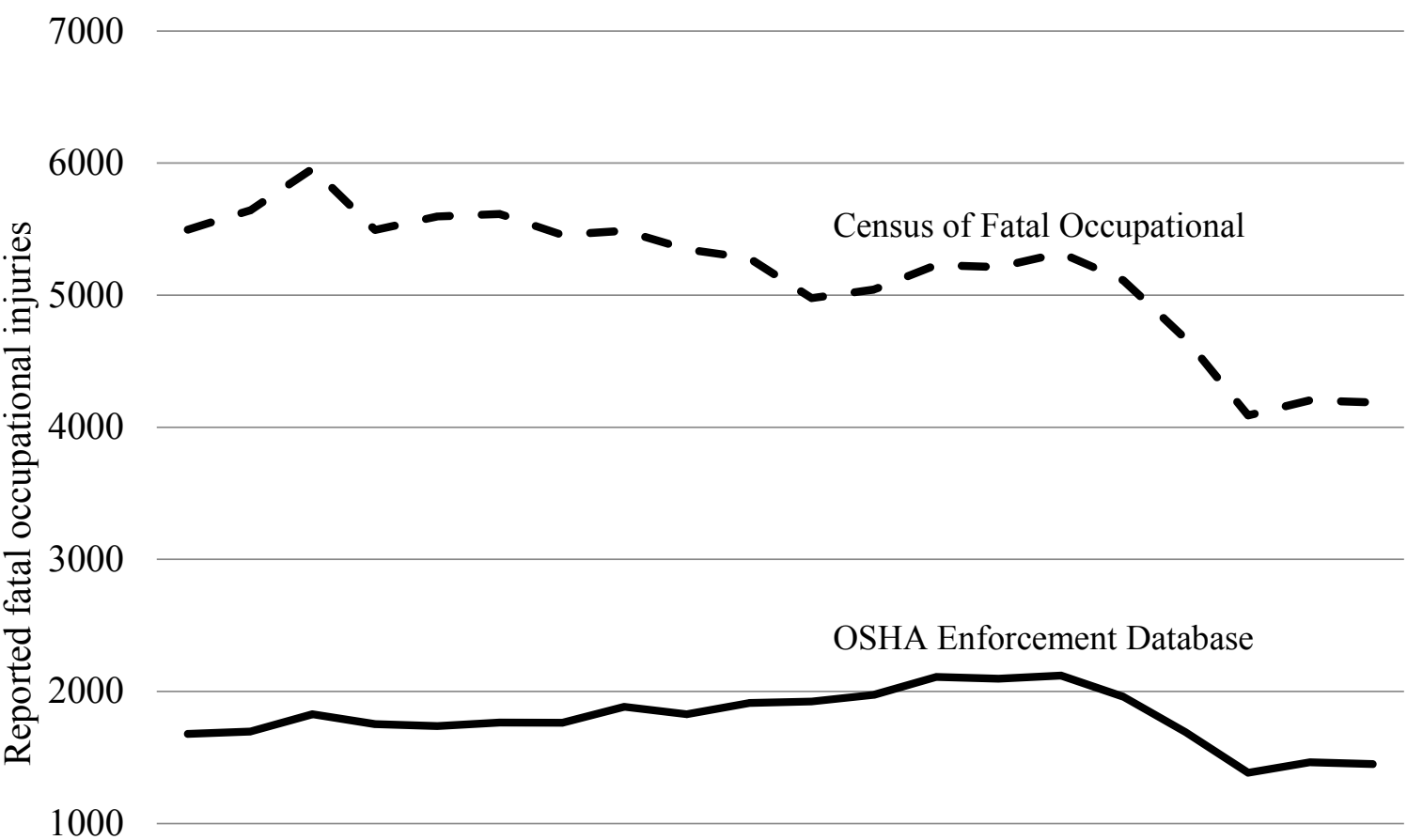

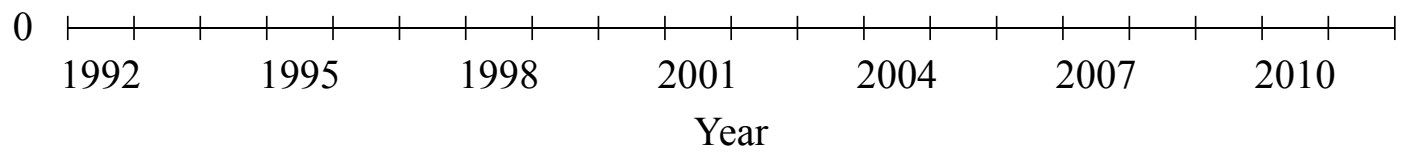

